\title{
Patience decreases with age for the poor but not for the rich: an international comparison
}

\author{
Giovanni Burro ${ }^{\mathrm{a}}$, Rebecca McDonald ${ }^{\mathrm{b}}$, Daniel Read ${ }^{\mathrm{c}, *}$, Umar Taj $^{\mathrm{c}}$ \\ a Bocconi University, Department of Finance and IGIER, via Roentgen 1, Milano, 20136, Italy \\ ${ }^{\mathrm{b}}$ Department of Economics, University of Birmingham, University House, Birmingham, B15 2TT, United Kingdom \\ ${ }^{c}$ Warwick Business School, The University of Warwick, Coventry, CV4 7AL, United Kingdom
}

\section{A R T I C L E I N F O}

\section{Article history:}

Received 1 February 2021

Revised 1 November 2021

Accepted 2 November 2021

\section{JEL classification:}

D15

D90

G59

Keywords:

Patience

Time Discounting

Age

Income

World

\begin{abstract}
A B S T R A C T
We introduce the Preference for Earlier versus Later Income (PELI) scale, measuring patience for over 50,000 individuals from 65 countries. We focus on the relationship between age and income on patience, two variables that have been widely studied in isolation. We find that, within countries, individuals in the richest income quintile are equally patient at any age while individuals in the poorest quintile are less patient the older they are. The relationships in the other quintiles are distributed in an orderly manner between these extremes. We derive a national patience index that correlates with characteristics linked to economic development, with cultural differences associated with patience, and with alternative more complex measures of patience. We recommend adopting PELI in international surveys.
\end{abstract}

(c) 2021 The Authors. Published by Elsevier B.V. This is an open access article under the CC BY license (http://creativecommons.org/licenses/by/4.0/)

\section{Introduction}

Patience, or the willingness to defer current consumption in exchange for greater future consumption, may be one of the most important ways individuals and societies vary. At the individual level, patience in childhood plays a crucial role in the development of successful and well-functioning adults (Mischel et al., 1989), and patience in adulthood is related to a variety of determinants of personal well-being (Madden and Bickel, 2010). At the societal level, patience underpins vital pathways to growth and development. For instance, the willingness to invest in long term projects with larger overall rewards is one driver of the adoption of new technologies and hence the development and growth of economies (Ramsey, 1928). A population with more patient entrepreneurs will invest in more ambitious long term projects. Patience plays a key role in many models of development such as Ramsey-Cass-Koopmans models, and models of accumulation of the stocks of physical capital, human capital, or research intensity (Becker, 1962; Ben-Porath, 1967; Doepke and Zilibotti, 2008; Dohmen et al., 2018; Galor and Özak, 2016; Sarid and Galor, 2017).

We contribute to the research on patience and intertemporal choice by drawing on a unique international dataset that includes a measure of individual patience, as well as fine-grained individual data covering key demographic and individual

\footnotetext{
* Corresponding author.

E-mail addresses: giovanni.burro@unibocconi.it (G. Burro), r.l.mcdonald@bham.ac.uk (R. McDonald), Daniel.Read@wbs.ac.uk (D. Read), Umar.Taj@wbs.ac.uk (U. Taj).
} 
difference factors. This is the Gallup End of Year Survey which in 2015 included our own measure of patience, which we call the Preference for Earlier versus Later Income (PELI). Respondents chose between receiving an amount equal to their normal monthly income today, or twice that amount in one year; those who chose to wait scored 1 on the PELI, and those who chose the immediate amount scored 0 . The survey was taken by a large sample (over 50,000 people) from 65 countries, allowing us to test new hypotheses and replicate previous tests with a new dataset.

As discussed in the next section, our primary focus is on individual characteristics and their universality, and especially how patience is related to age and wealth. Although both age and wealth have been related to patience in studies from both psychology and economics, the interaction between them has not yet received a comprehensive empirical test. Moreover, the large international sample and the substantial variety of individual characteristics included in our dataset enable us to test the robustness and generality of any observed relationships. Social scientists increasingly recognise the need to broaden the spectrum of societies that are studied. In particular, Henrich et al. (2010) advocate that we go beyond the borders of the WEIRD (western, educated, industrialized, rich and democratic) world.

We find that patience shows a clear relationship with age, income, and crucially also with their interaction. At a young age, people of all income groups show roughly the same degree of patience, but this changes as they get older. Older people are considerably more patient the higher their income. People with a lower income are considerably more patient if they are young than old. From this, we conclude that age is associated with constant patience in the rich and decreasing patience in the poor, and we show this relationship plays out consistently across age and income groups. We also find that women are more impatient than men, and atheists are more patient than protestants, who are more patient than other religious groups. Greater economic optimism, more education, and more positive attitudes toward vaccines are also associated with greater patience. Employed people, students and housewives are more patient than unemployed and "retired or disabled" individuals.

We find that higher GDP per capita, higher life expectancy, lower interest rates, higher Private Credit to GDP, higher distance from the Equator, and lower levels of inflation are positively and significantly correlated with country average PELI ${ }^{1}$. Country average PELI is also predicted by several social indices previously proposed as predictors of patience. As a general pattern, we find that countries belonging to Germanic, Nordic European and Anglo/American cultural clusters (Chhokar et al., 2008) show the highest levels of patience. We find that higher levels of Individualism and lower levels of Uncertainty Avoidance (Hofstede and Bond, 1988; Hofstede, 2001) are also positively and significantly correlated with the country average PELI. As predicted by Chen (2013), countries whose main language does not rely on the future tense have higher levels of patience. Importantly, we show that patience defined as the country average PELI is highly and significantly correlated to the measures of time preference adopted by Falk et al. (2018) and by Wang et al. (2016). Because PELI is measured with a single question that does not need to be customised at the country or individual level, there will be many circumstances where it has a distinct advantage.

\section{Time discounting, age and income}

Time discounting is a multifarious concept, but at its heart is the idea that people prefer a given degree of positive consumption to occur earlier rather than later. This specific claim is not generally the direct subject of empirical investigation, which instead tends to focus on proxy measures such as tradeoffs between money or goods over time. While these proxy measures can be objected to on theoretical grounds (Ramsey, 1928; Cubitt and Read, 2007), they are nonetheless associated with individual differences in impatience-related outcomes, such as smoking, obesity and financial well-being (Chabris et al., 2008), and have been widely accepted as providing a proxy for the discounting of consumption (Harrison et al., 2002(Cohen et al., 2020)). Perhaps the main reason they successfully capture individual differences is narrow bracketing (Read et al., 1999), in that people can generally be relied upon to ignore opportunity costs and therefore to make intertemporal monetary tradeoffs much as they might make consumption or "utility" tradeoffs (Andreoni et al., 2018).

One personal characteristic that has long been associated with patience is wealth. Even the earliest economists who made time preference a special focus of study universally expected that the poor would be more impatient than the rich (see the review in Loewenstein, 1992). Sometimes this expectation was based on the crushing effects of poverty itself (Fisher, 1930), sometimes on other correlates of poverty such as lack of education (Strotz, 1955), and sometimes impatience was treated as the cause of poverty (Ramsey, 1928). Fisher (1930) distinguished between explanations based on rational and irrational cognitive processes:

"This influence of poverty is partly rational, because of the importance, by supplying present needs, of keeping up the continuity of life and thus maintaining the ability to cope with the future; and partly irrational, because the pressure of present needs blinds a person to the needs of the future." (Fisher, 1930, p. 72).

Becker and Mulligan (1997) famously proposed one "rational" reason why the poor should discount more. They argued that patience is directly related to how much is invested in thinking about the future, and that the poor discount more because they have a bleak future which they are better off not thinking about.

\footnotetext{
1 As we later explain, country average PELI is the percentage of respondents in a country who choose the larger later reward.
} 
Empirical research has supported the prediction that greater wealth is associated with more patience. This is true in experimental and survey studies (Green et al., 1996; Meier and Sprenger, 2010; Poulos and Whittington, 2000; Tanaka et al., 2010), in estimates drawn from consumption data (Lawrance, 1991), and in field studies of choice behaviour (Hausman, 1979; Warner and Pleeter, 2001). Even experiments in which "wealth" is manipulated artificially show that the same people discount the future more when they are induced to think of themselves as poor rather than rich (Bickel et al., 2016; Haushofer and Fehr, 2019).

Age is also widely believed to affect patience. Unlike wealth, however, predictions concerning the effects of age differ widely because there are so many factors that might influence discounting over the lifespan, and these factors do not always work in the same direction. It was again the reliable Irving Fisher (1930) who offered one of the earliest and most comprehensive accounts of the relationship. The following lengthy passage, too rich to abbreviate, provides a vivid portrait of how and why a single individual's time preference might change over the lifespan:

Everyone at some time in his life doubtless changes his degree of impatience for income. In the course of an ordinary lifetime the changes in a man's degree of impatience are probably of the following general character: as a child he will have a high degree of impatience because of his lack of foresight and self-control; when he reaches the age of young manhood he may still have a high degree of impatience, but for a different reason, namely, because he then expects a large future income. He expects to get on in the world, and he will have a high degree of impatience because of the relative abundance of the imagined future as compared with the realised present. When he gets a little further along, and has a family, the result may be a low degree of impatience, because then the needs of the future rather than its endowment will appeal to him. He will not think that he is going to be so very rich; on the contrary, he will wonder how he is going to get along with so many mouths to feed. He looks forward to the future expenses of his wife and children with the idea of providing for them - an idea which makes for a high relative regard for the future and a low relative regard for the present. Then when he gets a little older, if his children are married and have gone out into the world and are well able to take care of themselves, he may again have a high degree of impatience for income, because he expects to die, and he thinks, “Instead of piling up for the remote future, why shouldn't I enjoy myself during the few years that remain?" (Fisher, 1930), pp.90-91.

Fisher emphasises multiple determinants of the age/patience relationship. Foresight, self-control, expectations and the bequest motive all combine to produce a "U-shaped" time course of discounting, with greatest impatience amongst the young and the old. Other theoretical accounts also predict this U-shaped pattern (Becker and Mulligan, 1997; Chu et al., 2010; Sozou and Seymour, 2003), and a number of empirical studies have reported a U-shaped pattern, or at least data highly suggestive of it, using standard discounting tasks (Bruderer Enzler et al., 2014; Falk et al., 2018; Harrison et al., 2002; Read and Read, 2004; Richter and Mata, 2018).

The U-shape is by no means the only theoretical prediction available, nor the only empirical result in the literature. Rogers (1994) developed the idea that discounting is a function of evolutionary fitness, and argued (approximately) that since younger people can transform resources into offspring much more easily than can older ones, younger people will discount at a higher rate. This pattern of impatience declining with age has also been reported frequently (Green et al., 1996, 1997; Lahav et al., 2010; Löckenhoff et al., 2011; Meissner et al., 2020; Reimers et al., 2009; Sparrow and Spaniol, 2018).

Yet another theoretical approach is that of Trostel and Taylor (2001) who proposed that discounting would be greater amongst the old than the young, because the ability to enjoy consumption decreases at an accelerating rate amongst the old. Empirical evidence consistent with this prediction has been reported by several researchers (Cropper et al., 1994; Eppinger et al., 2017; Kirby et al., 2002; Seaman et al., 2016). Moreover, to add to the diversity, some studies find no effect of age on patience (Chao et al., 2009), and, indeed, "no effect" was the conclusion of a recent meta-analysis focusing on contributions from psychology (Seaman et al., 2020).

The diverse observed effects of age can be reconciled if, as already anticipated by Fisher (1930), the many motives that influence discounting vary with age, and if people in different income groups place relatively more or less importance on these different motives over their lifetimes. For instance, Rogers's (1994) evolutionary fitness argument combined with a bequest motive could suggest older people will discount at a very low rate. If your personal reproductive capacity is restricted, but you have children or grandchildren who can benefit from your support, then you might discount at a low rate to leave something to your descendants to help them reproduce. But this might depend on the personal comfort of these older people. Someone who anticipates rapid decline in their ability to enjoy life might prioritise immediate consumption and so discount at a high rate, as suggested by Trostel and Taylor (2001) and in the passage by Fisher (1930), because they believe that now is their last opportunity to eke some pleasure from their life. The balance between competing motives can produce a "net" discount rate that might decrease, increase or stay constant with age.

We investigate the interaction between age, income, and patience. The only previous empirical study of this interaction is by Green et al. (1996). While their study is valuable, they did not obtain the (minimum) four cells of data needed to fully test for an age/income interaction. They reported on samples of wealthy older people and poor older people, and a sample of wealthy young people. They found that the wealthy older people were more patient than the poor older people, but that the wealthy younger people were just as patient as wealthy older people. The latter result suggests that discounting might not change with age, at least for the well-off. It is natural, however, to imagine that age and poverty might interact. In 
particular, one reason not to expect big differences amongst different wealth levels for the young is the idea, suggested also by Fisher, that all young people, independently of their financial situation, are likely to be optimistic and forward looking.

Both Ramsey (1928) and Becker and Mulligan (1997) suggest the gap in patience between individuals that are relatively richer and individuals that are relatively poorer should increase with age, with patience being greater for older individuals that are well-off. This claim is supported by Epper et al. (2020), who measured patience at a single point in time (between 32 and 42 years of age), and checked where individuals with a given level of patience ranked in the wealth and income distributions over their lifespan. Epper et al. (2020) split their sample into three groups, based on the patience level. Those showing high patience constantly ranked higher than others in the wealth distribution. Moreover, those in the most patient group earned a lower income than those in the low or middle patience groups when they were young but at some time in their 30s the ranking reversed and those in the high patience group had the highest income.

To understand the interplay between age, income and patience, we must also account for the effect of other individual level traits and characteristics where these have been found to matter in previous research. An example is sex. There has been much debate and little agreement over whether women or men are more patient. In several studies, women displayed more patience than men (Bauer and Chytilová, 2013; Dittrich and Leipold, 2014; Frederick, 2005; Silverman, 2003), but other studies have reported no effect, or a reverse effect. Of the international studies which are our immediate predecessors, Wang et al. (2016) found no effect of sex whilst Falk et al. (2018) found women to be less patient than men. Another demographic characteristic likely to matter is education, which has often been found to positively correlate with patience (Perez-Arce, 2017; Falk et al., 2018).

Turning to preferences and attitudes, risk attitude has frequently been compared to time preference, and Ferecatu and Önçüler (2016) found that participants willing to take risks were less patient. Anderhub et al. (2001) and Tanaka et al. (2010) also found that risk aversion is correlated with more patience. However, Falk et al. (2018) found the opposite effect. Another relevant attitude is optimism. For example, Ifcher and Zarghamee (2011) experimentally induced positive emotions (happiness) into subjects and this led them to show higher levels of patience, and previous research has indicated that perceived riskiness of a reward (which can be interpreted as pessimism about its receipt) may lead to greater impatience (Green and Myerson, 2004).

Finally, religious beliefs have been associated with patience. For example, Weber (1930) proposed the idea of a "protestant ethic" which was associated with a range of attributes related to the spirit of capitalism, including patience. Falk et al. (2018) found that the share of protestants in a given country is positively related to country-level patience. We also investigate the correlation between patience and respondents' religious beliefs at the individual level. Controlling for all these individual characteristics, attitudes, and beliefs is crucial to allow us to cleanly reveal the main associations of interest in our study: the interplay of age, income and patience.

\section{Patience around the world}

We do not limit our analysis to the determinants of individual level patience; we also investigate international patterns of patience, including comparisons across countries, while examining cultural, economic and geographic differences and how they are related to patience. As discussed, two previous studies have adopted such a global perspective, Wang et al. (2016) and Falk et al. (2018). Other studies have tested patience in smaller numbers of countries. These include Breuer et al., 2020; Du et al. (2002); Mahajna et al. (2008); Meissner et al., 2020 and Tan and Johnson (1996).

Wang et al. (2016) obtained data from 53 countries using a large-scale international survey on time preference comprising almost 7,000 undergraduate students in Economics, Finance or Business Administration. Time preferences were measured by asking three questions. First, their participants chose between " $\$ 3,400$ dollars this month" and " $\$ 3,800$ dollars next month." Then, they indicated which payment in one year, and which payment in ten years, would be equivalent in value to \$100 now. Wang et al. (2016) also tested whether and how demographic variables, economic factors, and a range of individual differences predicted patience. They found a small effect of age, with older students more willing to choose the delayed $\$ 3,800$ reward than younger ones. However, the student sample meant that there was very limited heterogeneity in respondents' ages. Three of Hofstede's cultural dimensions (Hofstede, 2001), measured at the individual level, were found to have an impact on patience: Individualism, Uncertainty avoidance, and Long Term Orientation. Higher levels of uncertainty avoidance were associated with more pronounced present bias, whereas higher degrees of individualism and long term orientation were associated with more patience. At the level of the country, GDP per capita was positively associated with patience. Whilst Wang et al. (2016) made a pioneering contribution, the lack of variation in age in their respondents means they did not explore the relationship between age, income and patience.

Falk et al. (2018) conducted a major study of global variation in economic preferences using their own Global Preferences Survey (GPS). As well as time preferences, they measured risk preferences, positive and negative reciprocity, altruism, and trust from 80,000 people in 76 countries. Time preference was measured by means of a quantitative and a qualitative measure, introduced by Falk et al. (2016). The quantitative measure involved five hypothetical binary choices between an immediate and a delayed payment. They employed an iterating "staircase" method to identify bounds around an indifference point. The monetary amounts were expressed in the relevant local currency, scaled relative to median household income in that country. The qualitative measure was a self-assessment of willingness to wait. Respondents were asked "how willing are you to give up something that is beneficial for you today in order to benefit more from that in the future?" 
Falk et al. (2018) combined the quantitative and qualitative measures to create a patience index. At the individual level, they found patience varied with age: middle-aged individuals were the most patient (or, least impatient), compared with the young and the elderly, showing a U-shaped pattern of impatience. Patience was also higher for individuals with higher cognitive ability and individuals with higher subjective maths skills. Females were more impatient than males. Finally, patience was positively related to savings and education. In a companion paper; Falk et al. (2019) found that patience is positively correlated with life expectancy at the individual level, where life expectancy is measured based on nationality, age and gender of the individual. In Falk et al. (2018), patience at the national level was correlated with many countrylevel variables. These included Individualism and Long-Term Orientation (Hofstede, 2001) measured at the national level; GDP per capita; geographic and biological variables that had previously been argued to be conducive for economic development (Diamond, 2005; Olsson and Hibbs, 2005; Spolaore and Wacziarg, 2013); the country's distance from the equator; the country's main language having weak Future Time Reference (Chen, 2013); pronoun drop not being allowed in the country's language (Tabellini, 2008); the proportion of protestants in the country (Weber, 1930; Doepke and Zilibotti, 2008) and general risk taking. In addition, they found a negative correlation between their index and the country-level intensity of family ties (Alesina and Giuliano, 2014). They found that western European and English speaking countries were the most patient. In particular, when comparing the effect of the preferences they estimated, Falk et al. (2018) found that time preference was much more strongly predictive of the GDP per capita of a country than were the other preference measures. Rieger et al. (2021) combined Falk et al. (2018) and Wang et al. (2016), along with several other international measures related to attitude toward time, into a composite measure they call "universal time preference."

\section{Data and methodology}

Our data come from the 2015 wave of the Gallup End of Year Survey. The survey was conducted from October to November 2015, with 66,040 respondents across 68 countries, of which 55,939 respondents across 65 countries answered the PELI question. The survey spans the entire income distribution in each country and also spans countries with very different characteristics and wealth. This enables us to investigate the relationship between patience, income and age.

The dependent variable is the Preference for Earlier versus Later Income (PELI) which was part of the End of Year Survey. This is a single question:

Think about your current household income: which of the following choices would you choose if offered?

- Today you receive an extra payment which is equal to that of your normal monthly income.

- In exactly one year from now you receive an extra payment equal to twice that of your normal monthly income.

The PELI was designed to "automatically" account for differences in currency. This made international comparisons possible without requiring transformation between currencies, PPP adjustment, or the inclusion of control questions. It also ensured that the amounts being evaluated were normalised based on the income of the respondent. By convention, we use the abbreviations SS (smaller-sooner) for the first option, and LL (larger-later) for the second option, and we use "patience" to refer to choices of LL. As we show later, PELI is highly correlated with other established measures of time preference that are more complex for respondents to answer and/or more time-consuming to elicit.

We obtained answers to the PELI from 55,939 individuals from 65 countries. Income information is available for 50,754 respondents. The number of respondents in each country making each choice, along with the percentage of respondents choosing LL, is reported in Table 2 and shown in Fig. 1. Table 1 lists the variables from the Gallup End of Year Survey that entered into our analysis.

\subsection{Analysis of patience at the individual level}

In addition to age and income and their interaction, we include in our empirical analysis a wide range of additional individual characteristics. Several of these have a well-established relationship with patience, and so serve as "sense checks" for the validity of the PELI, as well as providing further information on the generalizability of these earlier results. Others are novel or even exploratory. A.5 reports the exact questions asked.

We include key demographic variables. These are gender, education as indexed by a dummy variable indicating having a degree, and employment status indexed with dummies corresponding to the categories "Unemployed", "Housewife" (sic), "Retired/Disabled", "Student", and "Working Part-time" with "Working full-time" as the baseline. To capture respondents' risk preferences, we included a dummy variable taking the value of 1 if the respondent chose the safer out of a pair of options, consistent with them being relatively risk averse (see Table 1 for the wording of this question).

We also explore the effect of some more subjective opinions and beliefs about the future including respondents' feelings about their current situation and their beliefs about the future of their country. We include a dummy equal to 1 if the respondent stated they were happy or very happy about their life. Respondents also indicated if their country needed to change soon to become a better place ${ }^{2}$, and evaluated the economic outlook for their country in the coming year as negative, neutral or positive. Testing the association between these variables and patience reveals whether individuals who worry

\footnotetext{
2 Answers to this question were not recorded for Saudi Arabia.
} 


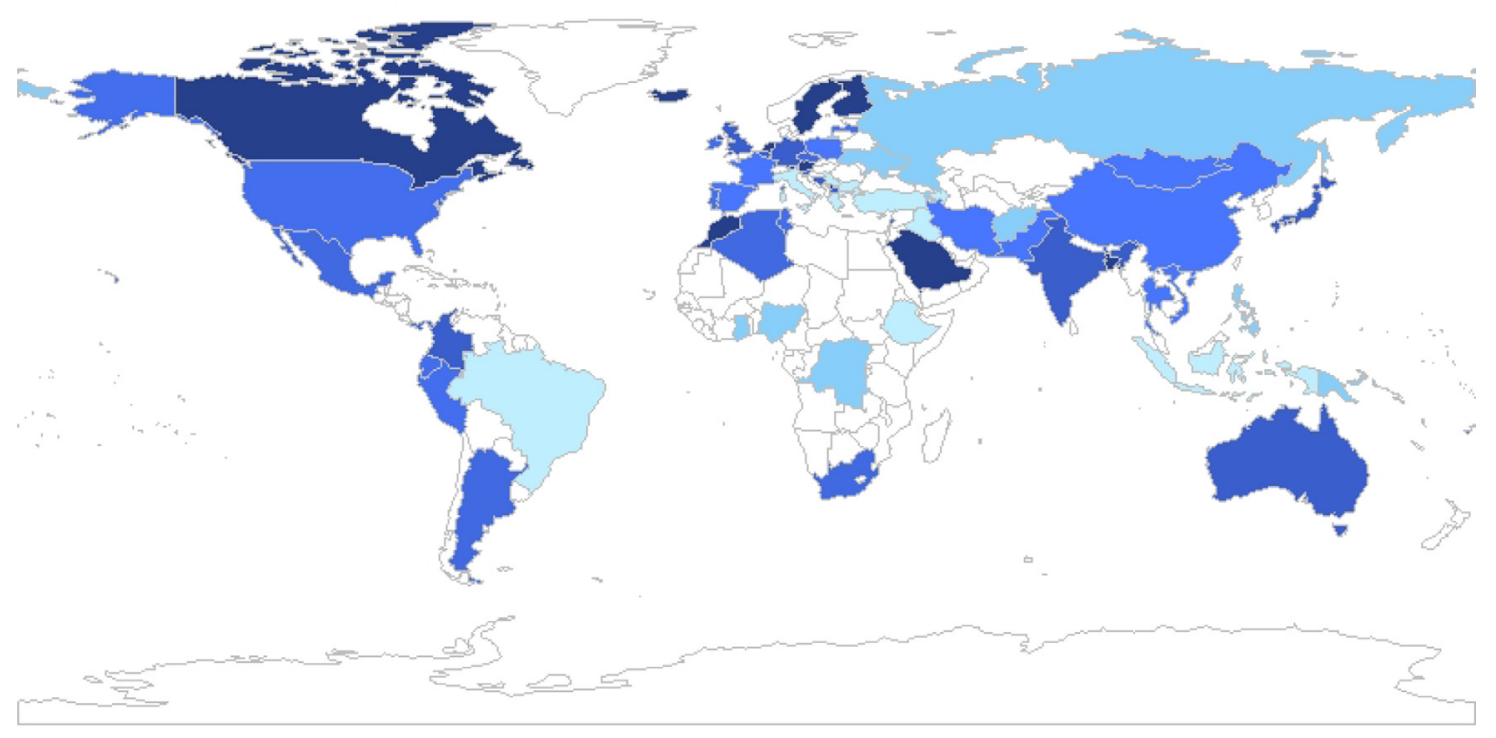

Fig. 1. Patience in the world. Dark shaded countries show a higher level of Patience. Patience index in each country is measured as the percentage of respondents who chose the LL option on the PELI. Based on 55,939 responses from 65 countries.

Table 1

Variables included in the analysis of individual-level patience. These variables come from the Gallup End of Year Survey 2015.

Income Quintile

Age

University degree

Employment

Next Year Outlook

Happy

Confidence Vaccine Effectiveness Religion

Change Soon

Risk Averse
Income quintile of the respondent in his or her country. Ordered as poorest, second poorest, middle, second richest, richest.

Age of the respondent.

A dummy equal to 1 if the respondent completed at least a university degree.

Employment of the respondent. Classified as Unemployed, Housewife, Retired/Disabled, Student, Working Part-time or Working full-time.

A dummy equal to 1 if the respondent answered "Economic Prosperity" to the question "Compared to this year, in your opinion, will next year be a year of economic prosperity, economic difficulty or remain the same for your country?"

A dummy equal to 1 if the respondent answered either "Happy" or "Very Happy" to the question "In general, do you personally feel very happy, happy, neither happy nor unhappy, unhappy or very unhappy about your life?"

Rate of agreement with the statement "Overall I think vaccines are effective."

Religion of the respondent. Possible answers were: Roman Catholic, Russian or Eastern Orthodox, Protestant, Other Christian, Hindu, Muslim, Jewish, Buddhist, Other, Atheist/Agnostic.

A dummy equal to 1 if the respondent answered either "In the short term" or "Right now" instead of "In the medium term", "In the long term" or "Never need to change" to the question "In your opinion, how soon does your country need to change to be a better place?"

"Think about your current household income: which of the following choices would you choose if offered?" A dummy equal to 1 if the respondent answered "A guaranteed increase in your household income of 50\%" instead of "A 50/50 chance to receive double your household income."

about the future are more impatient, since they may be more wary of forgoing rewards now in favour of those which are distant in time. This may be compounded by economic uncertainty that may lead to doubts about the future value of money.

Finally, we turn to beliefs related to identity. Respondents reported their belief in the effectiveness of vaccines ${ }^{3}$. While we know of no research comparing belief in vaccine effectiveness to patience, the willingness to vaccinate has been positively associated with patience (Nuscheler and Roeder, 2016). We capture belief in effectiveness using three dummies ranking the degree of belief in vaccine effectiveness, with strong agreement being the baseline. Lastly, we control for religious beliefs ${ }^{4}$, using Roman Catholic as the baseline.

The basic specification for our analysis, including only the effects of age and income, is:

$$
y_{i}=\alpha+\beta a_{i}+\gamma_{k} I_{k i}+\delta_{k} a_{i} * I_{k i}+\epsilon_{i} \quad i \in I ; \quad k \in\{2,3,4,5\}
$$

\footnotetext{
${ }^{3}$ Answers to this question were not recorded for Iraq.

${ }^{4}$ Answers to this question were not recorded for France, India and Japan.
} 
Table 2

Summary statistics on the PELI by country and macro area.

\begin{tabular}{|c|c|c|c|c|c|c|c|}
\hline Country/Macro Area & SS & LL & LL (perc.) & Country/Macro Area & SS & LL & LL (perc.) \\
\hline Overall & 28,439 & 27,500 & 0.49 & Mongolia & 488 & 459 & 0.48 \\
\hline Sweden & 260 & 649 & 0.71 & Argentina & 433 & 403 & 0.48 \\
\hline Finland & 314 & 708 & 0.69 & Algeria & 172 & 160 & 0.48 \\
\hline Netherlands & 306 & 608 & 0.67 & Mexico & 498 & 460 & 0.48 \\
\hline Austria & 300 & 596 & 0.67 & Panama & 565 & 501 & 0.47 \\
\hline Iceland & 276 & 524 & 0.66 & Slovenia & 486 & 428 & 0.47 \\
\hline Canada & 328 & 587 & 0.64 & Palestine (W Bank Gaza) & 459 & 393 & 0.46 \\
\hline Kosovo & 247 & 441 & 0.64 & Czech Republic & 494 & 405 & 0.45 \\
\hline Bangladesh & 282 & 493 & 0.64 & South Africa & 614 & 474 & 0.44 \\
\hline Saudi Arabia & 206 & 352 & 0.63 & Lebanon & 542 & 382 & 0.41 \\
\hline Morocco & 297 & 479 & 0.62 & Russia & 464 & 327 & 0.41 \\
\hline Germany & 348 & 553 & 0.61 & Ukraine & 239 & 162 & 0.40 \\
\hline Colombia & 379 & 587 & 0.61 & Papua New Guinea & 352 & 238 & 0.40 \\
\hline Japan & 345 & 494 & 0.59 & DR Congo & 506 & 342 & 0.40 \\
\hline Macedonia & 433 & 584 & 0.57 & Armenia & 524 & 352 & 0.40 \\
\hline United Kingdom & 380 & 511 & 0.57 & Ghana & 534 & 357 & 0.40 \\
\hline India & 446 & 587 & 0.57 & Afghanistan & 1,182 & 789 & 0.40 \\
\hline Australia & 441 & 574 & 0.57 & Nigeria & 477 & 310 & 0.39 \\
\hline Belgium & 380 & 493 & 0.56 & Philippines & 590 & 380 & 0.39 \\
\hline Bosnia Herzegovina & 410 & 527 & 0.56 & Serbia & 539 & 344 & 0.39 \\
\hline Latvia & 349 & 446 & 0.56 & Ethiopia & 605 & 334 & 0.36 \\
\hline United States & 403 & 501 & 0.55 & Greece & 619 & 331 & 0.35 \\
\hline Hong Kong & 191 & 233 & 0.55 & Italy & 547 & 292 & 0.35 \\
\hline Ecuador & 379 & 450 & 0.54 & Indonesia & 313 & 167 & 0.35 \\
\hline Ireland & 432 & 499 & 0.54 & Bulgaria & 568 & 300 & 0.35 \\
\hline Peru & 426 & 481 & 0.53 & Turkey & 617 & 262 & 0.30 \\
\hline Portugal & 471 & 481 & 0.51 & Iraq & 527 & 222 & 0.30 \\
\hline Tunisia & 407 & 414 & 0.50 & Brazil & 1,351 & 523 & 0.28 \\
\hline Fiji & 471 & 478 & 0.50 & Azerbaijan & 144 & 43 & 0.23 \\
\hline Thailand & 181 & 182 & 0.50 & North America & 731 & 1,088 & 0.60 \\
\hline Poland & 457 & 456 & 0.50 & Western Europe & 7,901 & 9,173 & 0.54 \\
\hline Pakistan & 460 & 455 & 0.50 & West South Asia & 2,370 & 2,324 & 0.50 \\
\hline France & 417 & 412 & 0.50 & East Asia and Oceania & 4,220 & 4,035 & 0.49 \\
\hline Vietnam & 284 & 278 & 0.49 & Eastern Europe & 3,000 & 2,780 & 0.48 \\
\hline China & 564 & 552 & 0.49 & Latin America & 4,031 & 3,405 & 0.46 \\
\hline Spain & 497 & 481 & 0.49 & MENA & 3,450 & 2,878 & 0.45 \\
\hline Iran & 223 & 214 & 0.49 & Sub-Saharan Africa & 2,736 & 1,817 & 0.40 \\
\hline
\end{tabular}

where $y_{i}$ takes the value of 1 if respondent $i$ chose LL on the PELI (i.e., was patient); $I_{k}$ are four dummies for the income distribution quintile (the first quintile is the baseline), and $a_{i}$ is the age (in decades) of respondent $i^{5}$. We fit a linear probability model, since this makes interpretation of the marginal effect of the interactions more straightforward (Ai and Norton, 2003).

To reduce the impact of inter-country variation, we included fixed effects at the country level ${ }^{6}$. In addition, we include the individual characteristics just summarised:

$$
y_{i}=\alpha+\beta a_{i}+\gamma_{k} I_{k i}+\delta_{k} a_{i} * I_{k i}+\omega x_{i}+\epsilon_{i} \quad i \in I ; \quad k \in\{2,3,4,5\}
$$

where the vector $x_{i}$ refers to the individual characteristics.

\subsection{Analysis of patience at the national level}

We next take a broader, country-level view by studying the heterogeneity of patience among countries. We take country average PELI, or the percentage of respondents choosing LL in each country, as reported in Table 2, as an index of patience for that country. We first test how well this measure correlates with those developed by Falk et al. (2018) and Wang et al. (2016). For Falk et al. (2018), we use the patience index available on the global preferences survey website. For Wang et al. (2016) we use the proportion of respondents choosing " $\$ 3,800$ dollars next month" over " $\$ 3,400$ dollars this month", in each country, as the patience index. In addition to testing the correlation with those other measures, we also investigate how PELI relates to several country characteristics that might be expected to correlate with patience.

\footnotetext{
${ }^{5}$ Age is reported in 6 bins in our data. We assigned the mid-point value to all individuals in a given bin and we treated age as a continuous variable. We did this to keep the interpretation simple, since having 4 dummies for the income quintile and 5 dummies for the age bins would have led to 20 interactions. In A.1, we repeat the analysis using the bins for age and the results are virtually unchanged (see Table A1 in A.1)

${ }^{6}$ We attempted to model heterogeneity among countries in different ways and results were robust across all specifications. We also repeat the analysis in sub-samples of the data both in Section 5 and in A.3, A.4.
} 
Table 3

Variables included in the analysis of country level patience. Sources of all variables are listed.

\begin{tabular}{|c|c|}
\hline GDP per capita & In 2014 and 2015 (World Bank). \\
\hline Growth Rate & In 2014 and 2015 (World Bank). \\
\hline Distance from Equator & Absolute latitude of the country. \\
\hline Private Credit to GDP & Ratio of domestic credit to the private sector over GDP in 2014 and 2015 (World Bank). \\
\hline Debt to GDP Ratio & In 2014 and 2015 (IMF). \\
\hline Gross savings to GDP & The difference between disposable income and consumption in 2014 and 2015 (World Bank). \\
\hline Life Expectancy & Measured at birth in 2014 and 2015 (World Bank). \\
\hline Real interest rate & $\begin{array}{l}\text { The lending interest rate in } 2014 \text { and } 2015 \text { adjusted for inflation as measured by the GDP deflator } \\
\text { (World Bank). }\end{array}$ \\
\hline Inflation rate & In 2014 and 2015 (World Bank). \\
\hline Future Time Reference (FTR) & $\begin{array}{l}\text { Developed by Chen (2013). It takes a value of } 1 \text { if a given language allows one to speak about the } \\
\text { future in the present tense (Weak FTR), and } 0 \text { otherwise (Strong FTR). }\end{array}$ \\
\hline Future Orientation Index (FOI) & $\begin{array}{l}\text { Developed by Preis et al. (2012). Ratio of Google queries looking for information on } 2016 \text { w.r.t. queries } \\
\text { looking for information on 2014. }\end{array}$ \\
\hline Individualism (IDV) & $\begin{array}{l}\text { It measures the degree to which the society reinforces individual or collective achievement, and the } \\
\text { extent to which people are expected to stand up as an individual as compared to loyal affiliation to a } \\
\text { life-long in-group (e.g., extended family, friends, etc.). Geert Hofstede's website ("2015 } 0816 \text { " version, } \\
\text { average value for each country). }\end{array}$ \\
\hline Uncertainty Avoidance (UAI) & $\begin{array}{l}\text { A high score of UAI indicates that a society is afraid of uncertain, unknown and unstructured situations. } \\
\text { Geert Hofstede's website ("2015 } 0816 \text { " version, average value for each country). }\end{array}$ \\
\hline Long Term Orientation (LTO) & $\begin{array}{l}\text { It captures the society's time horizon. It reflects to what extent a society has "a dynamic, } \\
\text { future-oriented mentality." A higher score implies that the past is valued less than the future, and } \\
\text { people may look more forward. Geert Hofstede's website ("2015 } 0816 \text { " version, average value for } \\
\text { each country). }\end{array}$ \\
\hline
\end{tabular}



Fig. 2. Patience by cultural cluster. Patience index in each cultural group is measured as the percentage of respondents who chose LL on the PELI. We group the countries into eight cultural clusters based on the classification from Chhokar et al. (2008).

These variables are summarised in Table 3, where we list the source for each. Fig. 1 and Fig. 2 give a sense of how PELI varies at the country level. In particular, we can group countries into eight cultural clusters, based on the classification of Chhokar et al. (2008), also adopted by Wang et al. $(2016)^{7}$ : Germanic and Nordic countries; Anglo/American countries;

\footnotetext{
7 We follow the classification of Chhokar et al. (2008), but aggregate clusters following Wang et al. (2016). More details on the classification are contained in A.6. We had to independently classify some countries while Wang et al. (2016) did not need to classify countries since they directly asked participants to classify themselves into the most appropriate cultural group.
} 
Asian countries; Latin European countries; Eastern European countries; Latin American countries; Middle Eastern countries ${ }^{8}$; African countries ${ }^{9}$. These groups are designed to maximize cultural homogeneity. Fig. 2 shows the average PELI in the eight cultural clusters. Consistent with Wang et al. (2016), we find that patience is highest in the Germanic and Nordic countries and lowest in the African countries. Anglo/American countries are the second most patient group, both in our analysis and in Wang et al. (2016). Other groups show very similar levels of patience and this is broadly consistent with Wang et al. (2016), with the only small difference that in their sample, Latin American and Latin European respondents have slightly lower level of patience than the rest.

Graham (1981) is an insightful resource on how the concept of time value of money changes for different cultures. To give a sense of cultural differences in this domain, Anglo-American cultures view time as a continuum stretching from past to present to future. In these cultures, time is considered to be an essential component of money (e.g., via discount rate/interest rate). On the other hand, Graham (1981) suggests that Latin American cultures perceive time as a circular concept that repeats itself with a cyclical pattern (e.g. mañana attitudes in Mexico). Wang et al. (2016) propose this as a possible explanation for the lower patience in Latin America and in Latin Europe, even though Latin Europe is closer to Western Europe regarding economic conditions.

To further explore countries' heterogeneity in terms of patience, we include in our analysis several measurable indicators which are commonly associated with patience. Since patience has historically been associated with different indicators of economic development (Becker, 1962; Ben-Porath, 1967; Doepke and Zilibotti, 2008; Dohmen et al., 2018; Galor and Özak, 2016; Sarid and Galor, 2017), we verify how our index correlates with some proxies for it. These are GDP per capita (World Bank); the growth rate (World Bank); and distance from the Equator ${ }^{10}$ measured in absolute latitude.

We also include four indices that account for the degree of indebtedness and the tendency to save for each country, since we might expect countries with more patient populations to have less debt and higher savings. First, we include the Debt to GDP ratio (IMF); second, Private credit to GDP ratio (World Bank); third, domestic credit to the private sector as a percentage of GDP; and fourth, Gross National Savings as a percentage of GDP. Other predictors include life expectancy at birth; the real interest rate; and the inflation rate $^{11}$. Macchia et al. (2018) experimentally found that higher inflation increases discounting ${ }^{12}$.

Finally, we include established sociological, linguistic and cultural measures that have previously been associated with patience. These include Future Time Reference (Chen, 2013), the Future Orientation Index (Preis et al., 2012), and three cultural dimensions (Hofstede and Bond, 1988; Hofstede, 2001). Future Time Reference takes a value of 1 if it is possible to refer to the future in the present tense in the language of the country (Weak FTR), and 0 otherwise. Chen (2013) proposed that languages with weak Future Time Reference would be associated with more patience because they treat the future as being just like the present, and this hypothesis was supported by Falk et al. (2018). We use the classification of languages adopted by Falk et al. $(2018)^{13}$. The Future Orientation Index is the ratio of the volume of internet searches for the next year to internet searches for the previous year. If the ratio of future over past searches is high, people in that group may be devoting more resources to thinking about the future than the past. We use the Future Orientation Index for the period spanned by our study, the ratio of searches for 2016 to searches for $2014^{14}$.

The cultural dimensions are Individualism, Uncertainty Avoidance, and Long Term Orientation measured at the country level. These were downloaded from Geert Hofstede's website. Individualism measures the degree to which the society reinforces individual versus collective achievement; Uncertainty Avoidance measures the general fear of uncertain, unknown and unstructured situations; and Long Term Orientation captures the extent to which a society has "a dynamic, futureoriented mentality." Wang et al. (2016) found that higher levels of Uncertainty Avoidance were associated with stronger hyperbolic discounting and higher present bias, whereas higher degrees of Individualism and Long Term Orientation predicted a stronger tendency to wait for larger payoffs. Falk et al. (2018) found Individualism and Long Term Orientation were correlated with patience.

\footnotetext{
8 This groups includes Northern African countries.

${ }^{9}$ This includes "Sub-Saharan Africa" but not South Africa which is in the Anglo/American cluster.

10 Geography has often been hypothesised to have an impact on economic development (Diamond, 2005; Spolaore and Wacziarg, 2013; Falk et al., 2018).

11 We use both the 2014 and the 2015 release of the key macroeconomic indices. This is because data were collected at the end of 2015 . Hence, if we seek to understand a correlation between patience and, say, economic development, the relevant comparison would be between patience measured in 2015 and outcomes such as GDP per capita measured at the end of that year. However, in some cases, the 2014 release is a more appropriate comparison because causality is expected to run in reverse. Take inflation, for example. When respondents answer the patience question, they may take into account expected inflation, and in doing so they may incorporate information from the previous year (2014) which has already been realised, as well as information on the current year (2015) which has not yet been realised at the time of the survey, but which respondents would be experiencing through their daily transactions.

12 They conducted an experiment with participants from two countries, Argentina and the UK, which have historically experienced very different levels of inflation. They experimentally varied the inflation rate the participants experience in the task and find that participants discounted more in a high inflation than in a low inflation condition. They also found that participants from Argentina discounted future rewards more steeply than participants from the UK and they attribute it to the fact that Argentina is the country with much higher current and historical inflation rates of the two.

${ }^{13}$ He slightly modified the one proposed by Chen (2013).

14 We thank Merve Alanyali for computing the Future Orientation Index.
} 
Table 4

Summary statistics on patience by age and income group. Income corresponds to the position of the respondent in the income distribution in her country of origin. LL stands for "Larger Later" and SS for "Smaller Sooner."

\begin{tabular}{|c|c|c|c|c|}
\hline Income Quintile & Age & LL (perc.) & LL & SS \\
\hline \multirow[t]{6}{*}{ Poorest } & 18 to 24 & 0.49 & 877 & 918 \\
\hline & 25 to 34 & 0.43 & 974 & 1293 \\
\hline & 35 to 44 & 0.39 & 712 & 1107 \\
\hline & 45 to 54 & 0.40 & 654 & 977 \\
\hline & 55 to 64 & 0.39 & 481 & 767 \\
\hline & $65+$ & 0.38 & 522 & 844 \\
\hline \multirow[t]{6}{*}{ Second Poorest } & 18 to 24 & 0.49 & 858 & 902 \\
\hline & 25 to 34 & 0.48 & 1389 & 1492 \\
\hline & 35 to 44 & 0.47 & 1075 & 1219 \\
\hline & 45 to 54 & 0.45 & 924 & 1117 \\
\hline & 55 to 64 & 0.44 & 681 & 875 \\
\hline & $65+$ & 0.44 & 569 & 715 \\
\hline \multirow[t]{6}{*}{ Middle } & 18 to 24 & 0.48 & 1001 & 1095 \\
\hline & 25 to 34 & 0.50 & 1666 & 1645 \\
\hline & 35 to 44 & 0.49 & 1423 & 1494 \\
\hline & 45 to 54 & 0.48 & 1125 & 1207 \\
\hline & 55 to 64 & 0.48 & 804 & 867 \\
\hline & $65+$ & 0.49 & 527 & 545 \\
\hline \multirow[t]{6}{*}{ Second Richest } & 18 to 24 & 0.53 & 696 & 628 \\
\hline & 25 to 34 & 0.53 & 1124 & 994 \\
\hline & 35 to 44 & 0.55 & 1052 & 871 \\
\hline & 45 to 54 & 0.53 & 904 & 791 \\
\hline & 55 to 64 & 0.55 & 661 & 532 \\
\hline & $65+$ & 0.54 & 400 & 342 \\
\hline \multirow[t]{6}{*}{ Richest } & 18 to 24 & 0.51 & 431 & 406 \\
\hline & 25 to 34 & 0.54 & 763 & 655 \\
\hline & 35 to 44 & 0.57 & 807 & 598 \\
\hline & 45 to 54 & 0.58 & 797 & 581 \\
\hline & 55 to 64 & 0.56 & 503 & 401 \\
\hline & $65+$ & 0.61 & 288 & 188 \\
\hline
\end{tabular}

\section{Results}

\subsection{Individual analysis}

Our main conclusion is that the relationship between age and patience depends on whether you are rich or poor. This is evident even in Table 4, which reports the raw percentages of respondents choosing LL stratified by age and income but not controlling for anything else. For the youngest group, the percentage of LL choices does not differ between income levels. However, patience systematically diverges by income group as a function of age. For the oldest group, the percentage of LL choices is lowest amongst the poorest (38\%), highest amongst the richest (61\%), and is distributed in order between these extremes.

Tables 5 and 6 report the results of our regression analysis. For the poorest quintile the marginal effect of age is negative and stable. For that group, for each additional ten years of age, the probability of choosing LL decreases by around $2 \%$, even when including country or macro area fixed effects and other controls. The marginal effect of age for the other income categories is given by the sum of the coefficient of age and the coefficient of age interacted with the income category. For the richest quintile the marginal effect of age is virtually zero, because whilst the main effect of age is negative, the interaction almost entirely offsets this main effect. This means the level of patience is constant across all age groups for the richest quintile.

For the intermediate income levels, patience declines with age but the slope of the decline decreases as income increases. To put numbers on it, we focus on the estimate of patience when taking into account age, income and country fixed effects only (column 2 in Table 5). With every additional ten years of age, patience declines at the following rates: $2.7 \%$ for the lowest and second-lowest income quintiles; $1.4 \%$ for the middle income quintile; $1.0 \%$ for the second richest quintile; and only $0.02 \%$ for the richest quintile. This is clear in Fig. 3, where we plot the estimated probability of choosing LL for all combinations of age and income ${ }^{15}$. Additional analyses confirm that what we see in Fig. 3 is a stable estimate of how patience varies within country as age and income change. We return to this point at the end of this section and in A.4, A.3.

Several individual difference variables predict patience. Women are less patient than men (around 3\%), consistent with Falk et al. (2018). Educated people with at least a college degree are almost 3\% more likely to choose LL, in line with recent research (Dohmen et al., 2018; Meissner et al., 2020; Perez-Arce, 2017). Unemployed people, and those who answered

\footnotetext{
15 We select the USA as an example, which fixes the vertical position of the plots.
} 
Table 5

Individual level patience. Linear probability model based on a sample of 65 countries.

\begin{tabular}{|c|c|c|c|c|c|c|}
\hline Dep Var: Larger Later & $(1)$ & $(2)$ & (3) & $(4)$ & $(5)$ & $(6)$ \\
\hline Age (decades) & $\begin{array}{l}-0.018^{\text {**** }} \\
(0.004)\end{array}$ & $\begin{array}{l}-0.027^{\text {*** }} \\
(0.004)\end{array}$ & $\begin{array}{l}-0.024^{* * *} \\
(0.005)\end{array}$ & $\begin{array}{l}-0.027^{* * *} \\
(0.004)\end{array}$ & $\begin{array}{l}-0.023^{* * *} \\
(0.004)\end{array}$ & $\begin{array}{l}-0.023^{* * *} \\
(0.005)\end{array}$ \\
\hline Second Poorest Quintile & $\begin{array}{l}0.017 \\
(0.029)\end{array}$ & $\begin{array}{l}0.024 \\
(0.024)\end{array}$ & $\begin{array}{l}0.017 \\
(0.026)\end{array}$ & $\begin{array}{l}0.021 \\
(0.024)\end{array}$ & $\begin{array}{l}0.015 \\
(0.025)\end{array}$ & $\begin{array}{l}0.016 \\
(0.027)\end{array}$ \\
\hline Middle Quintile & $\begin{array}{l}-0.001 \\
(0.029)\end{array}$ & $\begin{array}{l}0.004 \\
(0.024)\end{array}$ & $\begin{array}{l}0.0004 \\
(0.028)\end{array}$ & $\begin{array}{l}-0.001 \\
(0.024)\end{array}$ & $\begin{array}{l}-0.007 \\
(0.024)\end{array}$ & $\begin{array}{l}-0.012 \\
(0.025)\end{array}$ \\
\hline Second Richest Quintile & $\begin{array}{l}0.028 \\
(0.031)\end{array}$ & $\begin{array}{l}0.017 \\
(0.026)\end{array}$ & $\begin{array}{l}0.025 \\
(0.030)\end{array}$ & $\begin{array}{l}0.009 \\
(0.026)\end{array}$ & $\begin{array}{c}0.0004 \\
(0.026)\end{array}$ & $\begin{array}{l}0.005 \\
(0.027)\end{array}$ \\
\hline Richest Quintile & $\begin{array}{l}0.007 \\
(0.038)\end{array}$ & $\begin{array}{l}-0.003 \\
(0.031)\end{array}$ & $\begin{array}{l}0.001 \\
(0.035)\end{array}$ & $\begin{array}{l}-0.016 \\
(0.030)\end{array}$ & $\begin{array}{l}-0.024 \\
(0.030)\end{array}$ & $\begin{array}{l}-0.015 \\
(0.031)\end{array}$ \\
\hline Age *Second Poorest Quintile & $\begin{array}{l}0.007 \\
(0.006)\end{array}$ & $\begin{array}{l}0.003 \\
(0.005)\end{array}$ & $\begin{array}{l}0.006 \\
(0.005)\end{array}$ & $\begin{array}{l}0.003 \\
(0.005)\end{array}$ & $\begin{array}{l}0.003 \\
(0.005)\end{array}$ & $\begin{array}{l}0.002 \\
(0.005)\end{array}$ \\
\hline Age $*$ Middle Quintile & $\begin{array}{l}0.017^{\text {**** }} \\
(0.006)\end{array}$ & $\begin{array}{l}0.013^{* * * *} \\
(0.005)\end{array}$ & $\begin{array}{l}0.015^{\text {**** }} \\
(0.005)\end{array}$ & $\begin{array}{l}0.013^{* * *} \\
(0.005)\end{array}$ & $\begin{array}{l}0.012^{\text {*** }} \\
(0.005)\end{array}$ & $\begin{array}{l}0.011^{* *} \\
(0.005)\end{array}$ \\
\hline Age *Second Richest Quintile & $\begin{array}{l}0.022^{* * *} \\
(0.006)\end{array}$ & $\begin{array}{l}0.017^{* * * *} \\
(0.006)\end{array}$ & $\begin{array}{l}0.020^{\text {**** }} \\
(0.006)\end{array}$ & $\begin{array}{l}0.016^{* * * *} \\
(0.006)\end{array}$ & $\begin{array}{l}0.016^{* * *} \\
(0.006)\end{array}$ & $\begin{array}{l}0.014^{* *} \\
(0.006)\end{array}$ \\
\hline Age *Richest Quintile & $\begin{array}{l}0.032^{\text {**** }} \\
(0.007)\end{array}$ & $\begin{array}{l}0.025^{\text {**** }} \\
(0.006)\end{array}$ & $\begin{array}{l}0.030^{\text {**** }} \\
(0.007)\end{array}$ & $\begin{array}{l}0.025^{* * *} \\
(0.006)\end{array}$ & $\begin{array}{l}0.024^{* * *} \\
(0.006)\end{array}$ & $\begin{array}{l}0.020^{* * *} \\
(0.006)\end{array}$ \\
\hline Female & & & & $\begin{array}{l}-0.030^{* * *} \\
(0.006)\end{array}$ & $\begin{array}{l}-0.030^{* * *} \\
(0.006)\end{array}$ & $\begin{array}{l}-0.033^{* * *} \\
(0.006)\end{array}$ \\
\hline University Degree & & & & $\begin{array}{l}0.028^{* * *} \\
(0.007)\end{array}$ & $\begin{array}{l}0.029^{* * *} \\
(0.007)\end{array}$ & $\begin{array}{l}0.026^{* * * *} \\
(0.007)\end{array}$ \\
\hline Employment (ref: Full-time work) & & & & & & \\
\hline Unemployed & & & & & $\begin{array}{l}-0.048^{* * *} \\
(0.009)\end{array}$ & $\begin{array}{l}-0.043^{* * *} \\
(0.010)\end{array}$ \\
\hline Housewife & & & & & $\begin{array}{l}-0.003 \\
(0.014)\end{array}$ & $\begin{array}{l}-0.0002 \\
(0.014)\end{array}$ \\
\hline Retired/Disabled & & & & & $\begin{array}{l}-0.033^{* * *} \\
(0.012)\end{array}$ & $\begin{array}{l}-0.024^{* *} \\
(0.012)\end{array}$ \\
\hline Student & & & & & $\begin{array}{l}-0.007 \\
(0.018)\end{array}$ & $\begin{array}{l}-0.010 \\
(0.019)\end{array}$ \\
\hline Working Part-time & & & & & $\begin{array}{l}-0.010 \\
(0.010)\end{array}$ & $\begin{array}{l}-0.009 \\
(0.010)\end{array}$ \\
\hline Risk Averse & & & & & & $\begin{array}{l}0.089^{* * * *} \\
(0.021)\end{array}$ \\
\hline Happy & & & & & & $\begin{array}{l}0.024^{* * * *} \\
(0.008)\end{array}$ \\
\hline Next Yr Econ (ref: negative) & & & & & & \\
\hline Neutral & & & & & & $\begin{array}{l}0.020^{\text {** }} \\
(0.008)\end{array}$ \\
\hline Positive & & & & & & $\begin{array}{l}0.026^{* * *} \\
(0.009)\end{array}$ \\
\hline Observations & 50,754 & 50,754 & 50,754 & 50,565 & 49,766 & 45,228 \\
\hline Adjusted $\mathrm{R}^{2}$ & 0.010 & 0.054 & 0.018 & 0.055 & 0.056 & 0.063 \\
\hline Country FE & NO & YES & NO & YES & YES & YES \\
\hline Macro Area FE & NO & NO & YES & NO & NO & NO \\
\hline
\end{tabular}

Note: ${ }^{*} \mathrm{p}<0.1 ;{ }^{* *} \mathrm{p}<0.05 ;{ }^{* *} \mathrm{p}<0.01$; Clustered Standard Errors at Country Level.

"retired or disabled" in the employment question, are less patient than employed people, even after controlling for income. Individuals choosing the safer option in the risk preference question are around 9\% more likely to choose LL. This large effect is in line with other evidence that risk aversion is correlated with patience (Anderhub et al., 2001; Tanaka et al., 2010). Happy people are more patient: the probability of choosing LL increases by more than $2 \%$ for individuals who describe themselves as happy or very happy, compared to those who report lower levels, consistent with Ifcher and Zarghamee (2011).

Individuals who believe economic conditions in their country will improve are more patient than those who think they will get worse (around 2\%). Those who think that their country needs to "change soon" for the better are around $4 \%$ less likely to choose LL. Those who strongly disagree that vaccines are effective are more than $6 \%$ less likely than others to choose LL, in line with Nuscheler and Roeder (2016). Religion is a particularly strong predictor of patience. Atheists and Agnostics are more than 6\% more likely than Catholics to choose LL. Since Weber (1930), the so-called protestant ethic has been considered as a contributor to economic prosperity and indeed protestants are more patient than people from other major religions. But all religious groups, including protestants, are less patient than atheists or agnostics. This contradicts the idea, proposed by Becker and Mulligan (1997), that belief in the after-life lowers the discount rate.

We now dig deeper in the universality of our results. A natural question to ask is if the interaction effect between age and income holds across countries. Figs. 4 and 5 report the estimated probability of choosing LL for all combinations of age and income, in each of the eight cultural clusters of countries (Chhokar et al., 2008). These predictions are based on OLS 


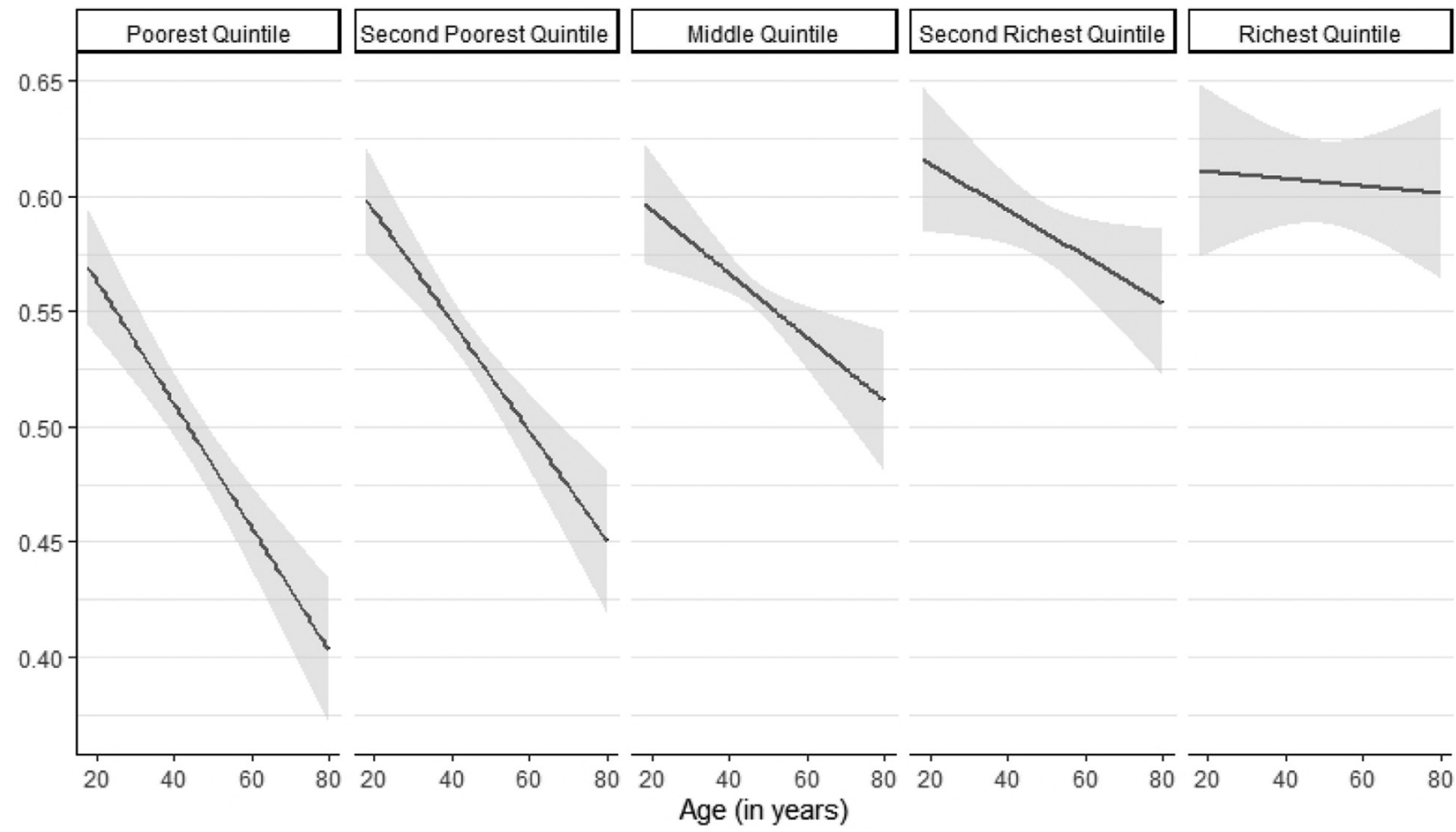

Fig. 3. Probability of choosing LL (patience) by age and income group. Estimated probability of choosing LL for each quintile of income. Predictions based on OLS regression model from column 2 of Table 5 with country fixed effects and clustered standard errors at country level (95\% confidence intervals) Country fixed to the United States of America.
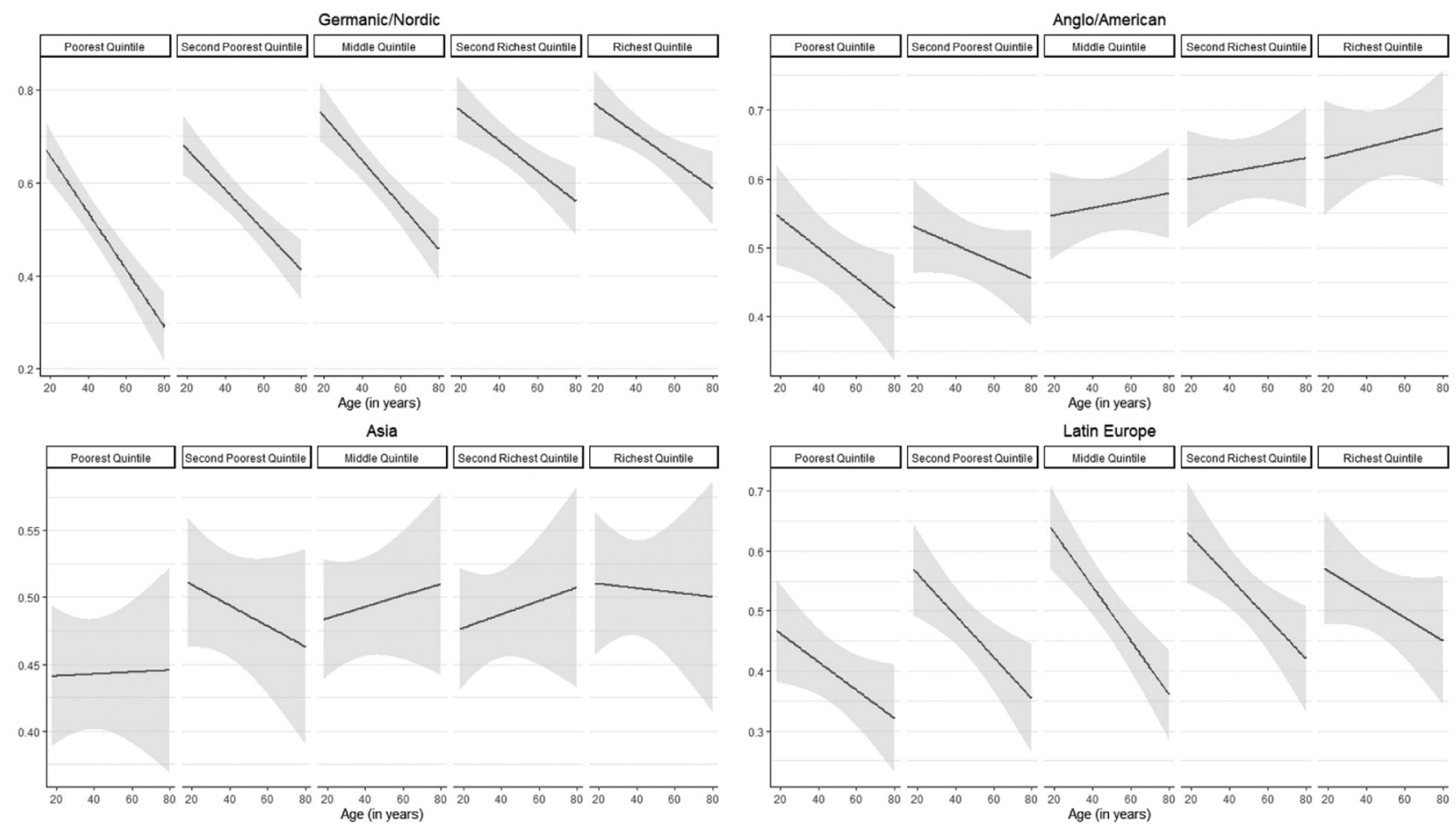

Fig. 4. Probability of choosing LL (patience) by age, income and cultural cluster. Estimated probability of choosing LL for each quintile of income. Predictions based on OLS regression with country fixed effects and clustered standard errors at country level (95\% confidence intervals). Country fixed to: Germany (Germanic/Nordic), the United States of America (Anglo/American), China (Asia) and France (Latin Europe). 
Table 6

Individual Level patience (extended). Linear probability model. Religions not significant, not shown. Income not significant, not shown. Employment status not significant, not shown.

\begin{tabular}{|c|c|c|c|c|}
\hline Dep Var: Larger Later & $(1)$ & $(2)$ & (3) & $(4)$ \\
\hline Age (decades) & $\begin{array}{l}-0.023^{* * *} \\
(0.004)\end{array}$ & $\begin{array}{l}-0.022^{* * *} \\
(0.005)\end{array}$ & $\begin{array}{l}-0.022^{* * *} \\
(0.005)\end{array}$ & $\begin{array}{l}-0.021^{* * *} \\
(0.005)\end{array}$ \\
\hline Age (decades) *Second Poorest Quintile & $\begin{array}{l}0.003 \\
(0.006)\end{array}$ & $\begin{array}{l}0.003 \\
(0.006)\end{array}$ & $\begin{array}{l}0.004 \\
(0.006)\end{array}$ & $\begin{array}{l}0.002 \\
(0.006)\end{array}$ \\
\hline Age (decades) *Middle Quintile & $\begin{array}{l}0.015^{* * *} \\
(0.005)\end{array}$ & $\begin{array}{l}0.013 * * * \\
(0.005)\end{array}$ & $\begin{array}{l}0.013^{* *} \\
(0.005)\end{array}$ & $\begin{array}{l}0.013^{* *} \\
(0.006)\end{array}$ \\
\hline Age (decades) *Second Richest Quintile & $\begin{array}{l}0.014^{* *} \\
(0.006)\end{array}$ & $\begin{array}{l}0.013 * * \\
(0.006)\end{array}$ & $\begin{array}{l}0.016^{* * * *} \\
(0.006)\end{array}$ & $\begin{array}{l}0.014^{* *} \\
(0.006)\end{array}$ \\
\hline Age (decades) *Richest Quintile & $\begin{array}{l}0.019^{* * *} \\
(0.006)\end{array}$ & $\begin{array}{l}0.019 * * * \\
(0.007)\end{array}$ & $\begin{array}{l}0.019^{* * * *} \\
(0.007)\end{array}$ & $\begin{array}{l}0.017^{* *} \\
(0.007)\end{array}$ \\
\hline Female & $\begin{array}{l}-0.030^{* * *} \\
(0.006)\end{array}$ & $\begin{array}{l}-0.031^{\text {*** }} \\
(0.006)\end{array}$ & $\begin{array}{l}-0.031^{\text {**** }} \\
(0.006)\end{array}$ & $\begin{array}{l}-0.027^{* * *} \\
(0.006)\end{array}$ \\
\hline University Degree & $\begin{array}{l}0.027^{* * *} \\
(0.007)\end{array}$ & $\begin{array}{l}0.026^{* * *} \\
(0.007)\end{array}$ & $\begin{array}{l}0.027^{* * *} \\
(0.007)\end{array}$ & $\begin{array}{l}0.027^{\text {**** }} \\
(0.007)\end{array}$ \\
\hline \multicolumn{5}{|l|}{ Employment (ref: Full-time work) } \\
\hline Unemployed & $\begin{array}{l}-0.040^{\text {**** }} \\
(0.010)\end{array}$ & $\begin{array}{l}-0.042^{* * *} \\
(0.011)\end{array}$ & $\begin{array}{l}-0.043^{* * * *} \\
(0.011)\end{array}$ & $\begin{array}{l}-0.042^{* * *} \\
(0.011)\end{array}$ \\
\hline Retired/Disabled & $\begin{array}{l}-0.019 \\
(0.012)\end{array}$ & $\begin{array}{l}-0.025^{* *} \\
(0.012)\end{array}$ & $\begin{array}{l}-0.023^{*} \\
(0.012)\end{array}$ & $\begin{array}{l}-0.019 \\
(0.012)\end{array}$ \\
\hline Risk Averse & $\begin{array}{l}0.093^{* * *} \\
(0.022)\end{array}$ & $\begin{array}{l}0.088^{* * *} \\
(0.021)\end{array}$ & $\begin{array}{l}0.089^{* * * *} \\
(0.022)\end{array}$ & $\begin{array}{l}0.092^{\text {**** }} \\
(0.023)\end{array}$ \\
\hline Happy & $\begin{array}{l}0.020^{\text {*** }} \\
(0.008)\end{array}$ & $\begin{array}{l}0.027^{* * *} \\
(0.008)\end{array}$ & $\begin{array}{l}0.022^{\text {**** }} \\
(0.009)\end{array}$ & $\begin{array}{l}0.020^{\text {*** }} \\
(0.008)\end{array}$ \\
\hline \multicolumn{5}{|l|}{ Next Yr Econ (ref: negative) } \\
\hline Neutral & $\begin{array}{l}0.018^{* *} \\
(0.008)\end{array}$ & $\begin{array}{l}0.016^{* *} \\
(0.008)\end{array}$ & $\begin{array}{l}0.018^{* *} \\
(0.009)\end{array}$ & $\begin{array}{l}0.013 \\
(0.009)\end{array}$ \\
\hline Positive & $\begin{array}{l}0.025^{\text {**** }} \\
(0.009)\end{array}$ & $\begin{array}{l}0.024^{* *} \\
(0.010)\end{array}$ & $\begin{array}{l}0.027^{* *} \\
(0.010)\end{array}$ & $\begin{array}{l}0.023^{* *} \\
(0.010)\end{array}$ \\
\hline Change Soon & $\begin{array}{l}-0.040^{* * *} \\
(0.009)\end{array}$ & & & $\begin{array}{l}-0.042^{* * *} \\
(0.009)\end{array}$ \\
\hline \multicolumn{5}{|c|}{ Confidence Vaccine Effectiveness (ref: Strong agree.) } \\
\hline Strong disagreement & & $\begin{array}{l}-0.062^{* * *} \\
(0.023)\end{array}$ & & $\begin{array}{l}-0.071^{* * *} \\
(0.023)\end{array}$ \\
\hline Moderate disagreement & & $\begin{array}{l}-0.009 \\
(0.013)\end{array}$ & & $\begin{array}{l}-0.003 \\
(0.013)\end{array}$ \\
\hline Moderate agreement & & $\begin{array}{l}-0.006 \\
(0.008)\end{array}$ & & $\begin{array}{l}-0.008 \\
(0.008)\end{array}$ \\
\hline \multicolumn{5}{|l|}{ Religion (ref: Catholic) } \\
\hline Atheist/Agnostic & & & $\begin{array}{l}0.062^{* * *} \\
(0.010)\end{array}$ & $\begin{array}{l}0.065^{\text {**** }} \\
(0.010)\end{array}$ \\
\hline Protestant & & & $\begin{array}{l}0.033^{* * *} \\
(0.010)\end{array}$ & $\begin{array}{l}0.033^{* * *} \\
(0.010)\end{array}$ \\
\hline Observations & 45,488 & 45,459 & 42,955 & 38,407 \\
\hline Adjusted $\mathrm{R}^{2}$ & 0.057 & 0.056 & 0.060 & 0.067 \\
\hline Country FE & YES & YES & YES & YES \\
\hline Countries number & 64 & 64 & 62 & 60 \\
\hline
\end{tabular}

Note: ${ }^{*} \mathrm{p}<0.1 ;{ }^{* *} \mathrm{p}<0.05 ;{ }^{* *} \mathrm{p}<0.01 ;$ Clustered Standard Errors at Country Level.

models which include age, income and country fixed effects, as in Table 5. The regression results are reported in Table A4. The patience divergence between the rich and the poor increases with age in almost all groups but it is more pronounced in the Germanic/Nordic and in the Anglo/American cultural clusters. An in-depth explanation of this finding is beyond the scope of this paper, but we speculate that one possible explanation relates to the causal chain that goes from patience to wealth. Countries with better functioning job markets are likely to present more opportunities for patient individuals to climb the income ladder.

In A.4 we also reproduce the analysis treating age as a categorical variable and find some evidence for non-linear relationships between patience and age in some income cells for some cultural groups (see Fig.s A3, A4) ${ }^{16}$. We also categorise countries based on GDP per capita and life expectancy at birth, in a supplementary analysis available here. The interaction effect is stronger in the richest and in the poorest countries and it is stronger in countries with high life expectancy. Although life expectancy has been found to predict patience (Bulley and Pepper, 2017; Falk et al., 2019), it does not fully explain our interaction result. We find that patience among the rich and poor starts to diverge at a young age, when even

\footnotetext{
${ }^{16}$ In some cells there are relatively few observations, which might lead to extreme results. For example, in the African cultural cluster, there are only 7 individuals in the richest quintile of income who are older than 65 and 6 of them chose LL.
} 

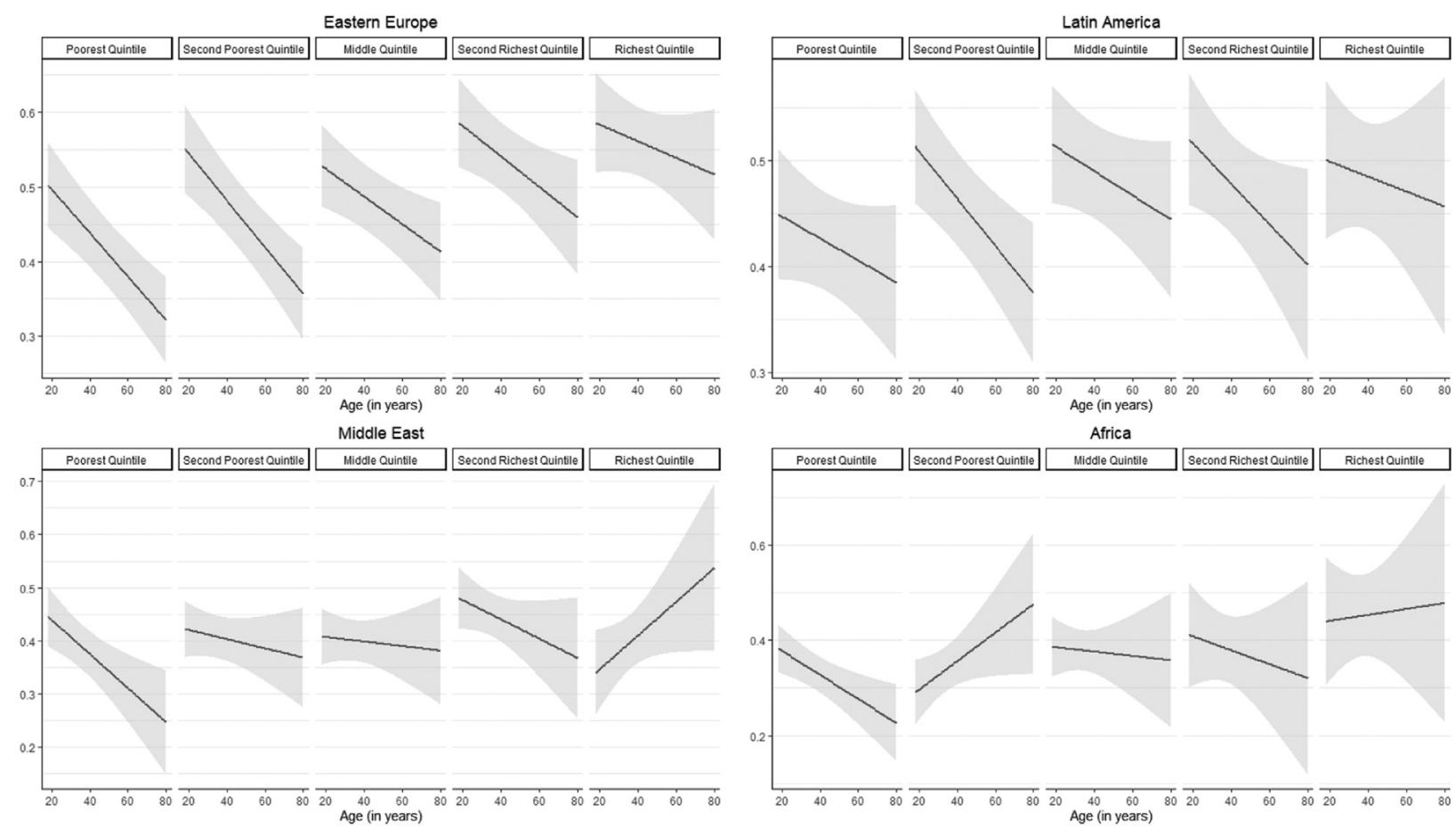

Fig. 5. Probability of choosing LL (patience) by age, income and cultural cluster. Estimated probability of choosing LL for each quintile of income. Predictions based on OLS regression with country fixed effects and clustered standard errors at country level (95\% confidence intervals). Country fixed to: Poland (Eastern Europe), Argentina (Latin America), Lebanon (Middle East) and Ethiopia (Africa).

respondents from countries where life expectancy is low (53 being the lowest in our sample, from Nigeria) should estimate the probability of living an extra year ${ }^{17}$ as very close to 1 . To give a sense of this, in countries in the lowest quintile for life expectancy, the percentage of respondents choosing LL in the poorest quintile of income is 0.41 at ages 18 to $24,0.38$ at 25 to 34 and 0.32 at 35 to 44 . The corresponding figures in the richest quintile of income are $0.42,0.49$ and 0.49 .

\subsection{Patience around the world}

As is evident from Table 5 country level fixed characteristics account for most of the explained variation in patience. Moreover, as seen in Fig.s 4, 5 there is considerable heterogeneity among the countries. Here we investigate what it is about the countries that determines patience. We treat the percentage of respondents choosing LL in each country, reported in Table 2 and shown in Fig. 1, as an index of national patience (or, country level PELI). Table 7 shows the correlation of this country level PELI with the alternative country level indices from Wang et al. (2016), Falk et al. (2018) and a new "universal" measure proposed by Rieger et al. (2021) that aggregates a number of measures (including Falk et al., 2018; and Wang et al., 2016). As can be seen, the correlations indicate a high level of criterion validity for the PELI, displaying correlations with other measures closer or higher than those between Falk et al. (2018) and Wang et al. (2016) themselves ${ }^{18}$. If we restrict ourselves to the 23 countries shared by all three measures, as shown in Table 8 , we see that this conclusion is supported, with the PELI displaying at least as high a correlation with the alternative measures as they do with one another. Overall, the highest correlations are between the country level PELI and Falk et al. (2018), with $\rho=.605$ on the set of countries shared with us, and 0.593 on those also shared with Wang et al. (2016).

Table 7 also displays correlations between country characteristics and national patience. National patience is correlated in the expected direction with indicators of economic development, including GDP per capita, life expectancy, the real interest rate, inflation, the private credit to GDP ratio, and distance from the equator. There is no significant correlation with the savings rate, the growth rate, or the debt to GDP ratio. In particular, a positive relationship between life expectancy and the national level willingness to wait from Wang et al. (2016) has already been reported by Bulley and Pepper (2017).

Of the three Hofstede measures, both Uncertainty Avoidance and Individualism are positively correlated with national patience, in line with Falk et al. (2018). The effect of individualism is consistent with Triandis (1971) in which participants from more individualistic cultures seemed more "willing to defer gratification."

\footnotetext{
17 The delay to the later reward in the PELI.

18 The correlation between Falk et al. (2018) and Wang et al. (2016) is $\rho=.480$ on the 34 common countries.
} 
Table 7

Patience correlation. Pearson correlation of the PELI index (proportion of respondents in a country who chose LL) with other indices and country level variables. Countries column reports the number of countries on which the correlation is calculated.

\begin{tabular}{|c|c|c|}
\hline & Corr. to Country Level PELI & Countries \\
\hline Patience Falk et al. (2018) & $0.605^{* * *}$ & 44 \\
\hline Patience Wang et al. (2016) & $0.439 * *$ & 28 \\
\hline Patience Rieger et al. (2021) & $0.507^{* * *}$ & 56 \\
\hline GDP per capita 2014 & $0.528^{* * *}$ & 65 \\
\hline GDP per capita 2015 & $0.521^{* * *}$ & 65 \\
\hline Life Expectancy 2014 & $0.433^{* * *}$ & 65 \\
\hline Life Expectancy 2015 & $0.435^{* * *}$ & 65 \\
\hline Real Interest Rate 2014 & $-0.444 * * *$ & 44 \\
\hline Real Interest Rate 2015 & $-0.496 * * *$ & 43 \\
\hline Inflation 2014 & $-0.271^{* *}$ & 64 \\
\hline Inflation 2015 & $-0.256^{* *}$ & 64 \\
\hline Private Credit to GDP 2014 & $0.329^{* * *}$ & 63 \\
\hline Private Credit to GDP 2015 & $0.324^{* *}$ & 63 \\
\hline Distance from Equator & $0.320^{* * *}$ & 65 \\
\hline Gross Savings 2014 & 0.082 & 62 \\
\hline Gross Savings 2015 & 0.156 & 62 \\
\hline Growth Rate 2014 & -0.068 & 65 \\
\hline Growth Rate 2015 & 0.095 & 65 \\
\hline Debt to GDP Ratio 2014 & 0.113 & 63 \\
\hline Debt to GDP Ratio 2015 & 0.066 & 63 \\
\hline Uncertainty Avoidance (Hofstede) & $-0.376^{* *}$ & 43 \\
\hline Individualism (Hofstede) & $0.361^{* *}$ & 43 \\
\hline Long Term Orientation (Hofstede) & -0.010 & 53 \\
\hline Future Time Reference Weak & $0.270^{* *}$ & 61 \\
\hline Future Orientation Index & 0.173 & 63 \\
\hline
\end{tabular}

Note: ${ }^{*} \mathrm{p}<0.1 ;{ }^{* *} \mathrm{p}<0.05 ;{ }^{* * *} \mathrm{p}<0.01$

Table 8

Correlations on the subset of countries common to three studies $(\mathbf{n}=\mathbf{2 3})$.

\begin{tabular}{lll}
\hline & Country level PELI & Patience Wang et al. (2016) \\
\hline Country level PELI & & $0.476^{* *}$ \\
Patience Falk et al. (2018) & $0.593^{* * *}$ & $0.465^{* *}$ \\
\hline
\end{tabular}

Note: ${ }^{*} \mathrm{p}<0.1 ;{ }^{* *} \mathrm{p}<0.05 ;{ }^{* * *} \mathrm{p}<0.01$

Unlike Wang et al. (2016) and Falk et al. (2018), we do not find any correlation between Long Term Orientation and national patience. The correlation between Long Term Orientation and Falk et al.'s (2018) measure is actually stronger in those countries that we do not study. The correlation drops from 0.44 , on the entire set of countries which Falk et al. consider to 0.27 (significant at the $10 \%$ level) on the set of countries that overlaps with ours. There is even a small (but non-significant) increase in the correlation between our national patience measure and Long Term Orientation (from -0.01 to 0.05) when we go from our full set to the overlapping set. Clearly, there is more to be learned on this issue.

In line with Falk et al. (2018), we find a positive correlation between national patience and weak Future Time Reference. We find no significant correlation between national patience and the Future Orientation Index (Preis et al., 2012).

\section{Conclusion}

We measured patience all over the world by means of the Preference for Earlier versus Later Income (the PELI), a single and easy to apply question that controls for income and currency. We identified a previously undiscovered interaction between age and income: poorer people are less patient the older they are, but the richest are equally patient at any age. This means the old poor are much less patient than the old rich, even though the young are equally patient no matter their income. We consider two possible directions of causality for this result. Either lower income leads to reduced patience over time, or lower patience leads to reduced income over time.

The possibility that lower incomes lead to lower patience with age is consistent with an emerging literature on the relationship between poverty, decision making and patience. Poorer people have more immediate financial constraints, and consequently even if they wish to make decisions that are better in the long term, they may be unable to do so (Mani et al., 2013; Bartoš et al., 2021). Loibl (2017, p. 428) describes the challenges of poverty in older age: "Difficulties adjusting to the lower pension income in early retirement, higher health care expenses, increasing demands to pay towards the cost of care, and the need to modify the home to meet changing health needs are the reasons for tight financial situations in older age (Bucher-Koenen and Lusardi, 2011; van Rooij et al., 2011)." Relative to the rich, the poor might therefore discount the future more as they get older because they will be more strongly affected by Fisher's "pressure of pressing needs." Becker and Mulligan's (1997) theory is also consistent with this: while people may not be born with different discount rates, those 
who are well off will find it worthwhile to expend resources in thinking about the future while the poorer will not, so the "patience gap" between rich and poor will increase with age. Indeed, the poor can expect a shorter life than the better off (Chetty et al., 2016), giving them even less reason to ponder their future.

The alternative proposal reverses the causal arrow. Ramsey (1928) suggested that those who are more patient will become better off as they get older, while those who are less patient will become worse off. The logic is that in a population where wealth and patience are randomly distributed at the beginning, those who are more patient will become richer, and those who are less patient will become poorer. With age (measured cross-sectionally) those with the highest income when older would therefore be more patient than those with the lowest income, while in their early years those with higher and lower income would not differ appreciably. As we mentioned earlier, this is one plausible reason why our result is stronger in countries likely to have a better functioning job market.

These two accounts, for different reasons, suggest that a sample of poor elderly people will be less patient than a sample of wealthy elderly people, but that this difference may not be observed for younger people.

The idea that patience causally increases wealth and our results are consistent with those reported in Epper et al. (2020). Their design involves some longitudinal data which we do not have, but we also complement their design. Epper et al. (2020) had access to a single measure of discounting for Danish residents, taken between the ages of 32 and 42 , as well as detailed measures of income and wealth taken over the ages of 18 to 40 . They therefore had cross-sectional data on time preferences, like ours, comparing the income of 40 year olds varying in patience (their groups were classed as patient, middle and impatient). They found that the patient group had higher incomes than the middle group, who in turn had higher incomes than the impatient group. We looked for a corresponding pattern in our data and the analyses are reported in A.2. We divided our sample into patient (i.e., chose LL) and impatient (chose SS) and compared the income of patient groups with impatient groups at every age. Our results for the approximately 40 year old group match Epper et al.'s (2020) qualitatively - the patient group had a significantly higher income. This pattern of higher income for more patient participants held at all age levels except the youngest ${ }^{19}$.

Our evidence also complements that of Green et al. (1999) and Huffman et al. (2019). Huffman et al. (2019) showed, as we did, that older wealthier people were more patient than older poorer people. Green et al. (1999) found this, and also (just as we did) found that older and younger wealthy people were equally patient. Green et al. (1999) concluded that discounting might not change with age, but they were not able to compare younger wealthy people to younger poor people. When we make this comparison, we find young wealthier people to have the same level of patience as young poorer people. The consistency of our results with comparable results in this literature, as well with the extensive research already discussed, adds credibility to our novel findings.

To conclude we recommend the PELI as an exceedingly simple measure of patience (or, delay discounting) which correlates very well with the main economic indicators and other apparently more sophisticated measures. Most importantly, it correlates very well with the measures developed by Falk et al. (2018) and Wang et al. (2016). It has the advantage of being much easier to elicit and it automatically overcomes many problems due to having different currencies and different economic conditions from one country to another. It directly addresses the actual financial situation of respondents and does not involve any demanding mathematical calculations on their part. We suggest it can make a valuable and feasible addition to international surveys, like the World Value Survey and all its national or international equivalents, where survey space is at a premium but a meaningful measure of individual and/or national patience is desirable.

\section{Acknowledgements}

We are indebted to Gallup International for inviting us to include two questions in their 2015 End of Year Survey and for giving us access to the data. Giovanni Burro acknowledges the support of the Leverhulme Trust, through the Bridges doctoral scholarship. Daniel Read and Rebecca McDonald acknowledge the assistance of the Economic and Social Research Council [grant number ES/P008976/1]. Shushan Li provided invaluable research assistance as part of her MSc dissertation. We also learned a lot from participants of SABE/IAREP Dublin 2019, SPUDM Amsterdam 2019, and the attendees at a workshop at the Booth School of Business, April 2021. The editor, two referees, Sanjong Misra, Redzo Mujcic, Nattavudh Powdthavee, Marc Scholten, Chris Starmer, Peter Wakker, and especially Merve Alanyali all contributed to the development of the paper. A longer version of this paper, containing more analyses in the appendix, is available here. Data and code are available here.

\section{Declaration of Competing Interest}

None.

\footnotetext{
19 At younger ages (18 to 27), Epper et al. (2020) actually found that patient individuals had a lower income than impatient ones. However, as we already stressed, patience was measured at around age 40 while income was measured at younger ages. They rely on the implicit assumption that patience is stable throughout the life span.
} 


\section{Appendix A}

\section{A.1. Age as a categorical variable}

Several studies have reported a non linear relationship between age and patience(Bruderer Enzler et al., 2014; Falk et al., 2018; Harrison et al., 2002; Read and Read, 2004; Richter and Mata, 2018). The framework we proposed in Equation (1) does not allow us to document such a pattern, since we included age as a linear predictor. Here, we show that analysing age as a categorical variable does not produce any non-linear patterns. In Table A1 we report the outcome of the following model, controlling for country fixed effects:

$$
y_{i}=\alpha+\beta_{z} a_{z i}+\gamma_{k} I_{k i}+\delta_{z k} a_{z i} * I_{k i}+\omega x_{i}+\varepsilon_{i} \quad i \in I ; \quad z \in\{2,3,4,5,6\} ; \quad k \in\{2,3,4,5\}
$$

where $y_{i}$ takes the value of 1 if respondent $i$ chose LL; $I_{k}$ are four dummies for the four quintiles of the income distribution (the first is the baseline), and $a_{z}$ are five age dummies. The first group (the baseline) is 18 to 24 years, then 25 to 34,35 to 44,45 to 54,55 to 64 and individuals above 65 . Hence, there are 20 interactions between age and income categories. As before, the vector $x_{i}$ refers to individual characteristics. Table A1 reports the outcome of the regressions. Given that the effects of age and income depend on so many coefficients, it is easier to visualise the relationship between patience, age and income by observing Fig. A1. Fig. A1 reports an out of sample prediction for USA citizens, for a regression where age and income are considered as categorical variables and country fixed effects are added (hence the model reported in Equation (1) where no other individual characteristics $x_{i}$ are considered). These predictions are equivalent to those in Fig. 3 , where age was fitted as a continuous variable. We see that the pattern in Fig. A1 can be conveniently approximated by linear trends. Patience decreases with age for any income category and the marginal decrease is weaker, the higher is the income. The richest quintile of income shows constant patience for any level of income. This confirms that no U-shaped pattern is present in our data.

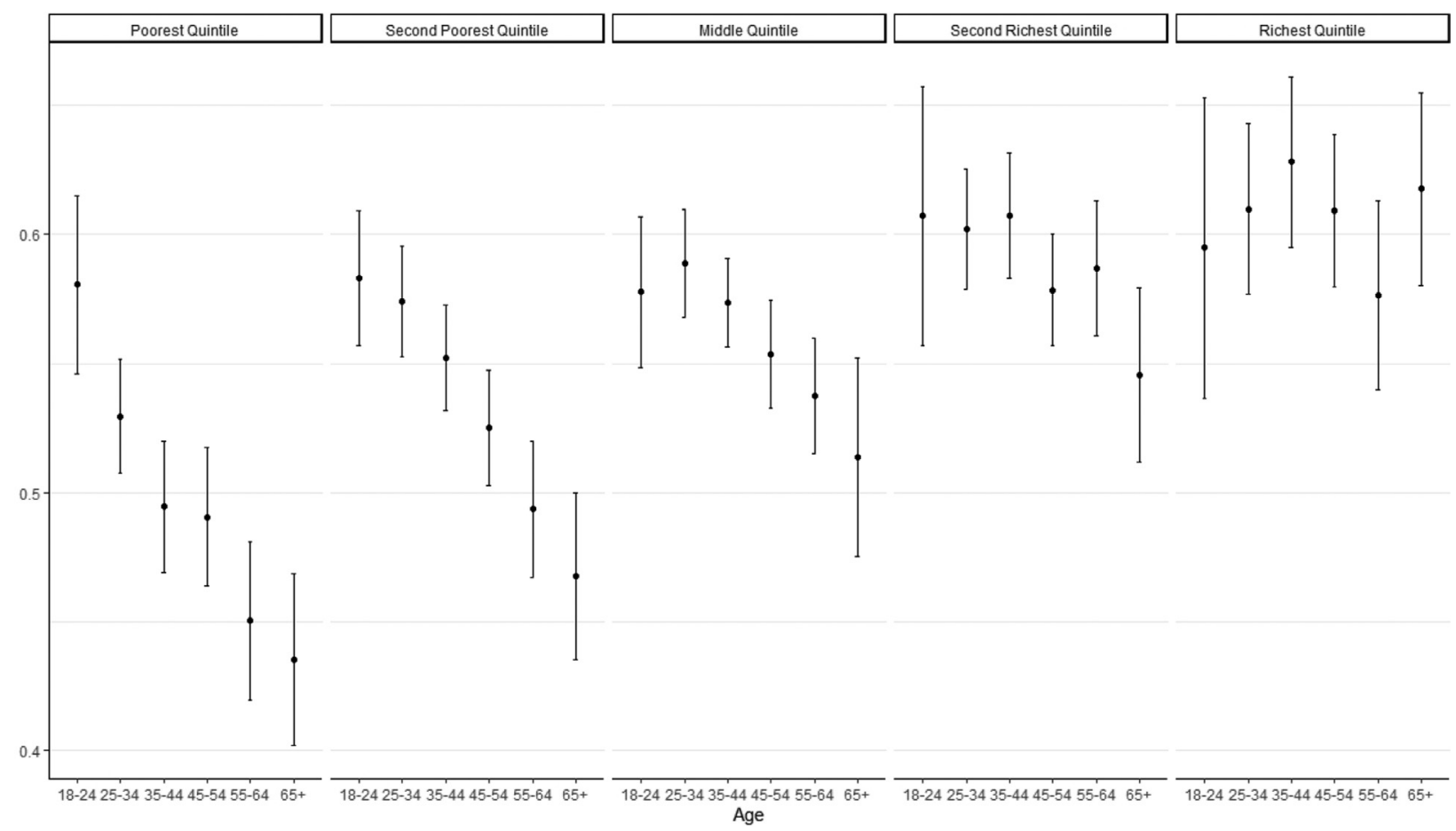

Fig. A1. Probability of choosing LL (patience) as a function of age and income. Estimated probability of choosing LL for each quintile of income. Predictions based on OLS regression model from column 2 of Table A1 with country fixed effects and clustered standard errors at country level (95\% confidence intervals). Country fixed to the United States of America. Age and income are both categorical variables. 
Table A1

Age bins regression. Linear probability model. Demographic controls in column (3) are the same as in column (4) from Table 6.

\begin{tabular}{|c|c|c|c|}
\hline Dep Var: Larger Later & $(1)$ & $(2)$ & (3) \\
\hline Age Bin 2 & $\begin{array}{l}-0.059^{* * * *} \\
(0.021)\end{array}$ & $\begin{array}{l}-0.051^{* * * *} \\
(0.018)\end{array}$ & $\begin{array}{l}-0.042^{*} \\
(0.025)\end{array}$ \\
\hline Age Bin 3 & $\begin{array}{l}-0.097^{* * *} \\
(0.026)\end{array}$ & $\begin{array}{l}-0.086^{* * *} \\
(0.021)\end{array}$ & $\begin{array}{l}-0.066^{* *} \\
(0.027)\end{array}$ \\
\hline Age Bin 4 & $\begin{array}{l}-0.088^{* * * *} \\
(0.024)\end{array}$ & $\begin{array}{l}-0.090^{* * * *} \\
(0.023)\end{array}$ & $\begin{array}{l}-0.077^{* * * *} \\
(0.027)\end{array}$ \\
\hline Age Bin 5 & $\begin{array}{l}-0.103^{* * * *} \\
(0.025)\end{array}$ & $\begin{array}{l}-0.130^{* * *} \\
(0.023)\end{array}$ & $\begin{array}{l}-0.100^{* * *} \\
(0.028)\end{array}$ \\
\hline Age Bin 6 & $\begin{array}{l}-0.106^{* * *} \\
(0.027)\end{array}$ & $\begin{array}{l}-0.145^{* * *} \\
(0.024)\end{array}$ & $\begin{array}{l}-0.112^{* * *} \\
(0.027)\end{array}$ \\
\hline Second Poorest Quintile & $\begin{array}{l}-0.001 \\
(0.027)\end{array}$ & $\begin{array}{l}0.002 \\
(0.022)\end{array}$ & $\begin{array}{l}0.001 \\
(0.026)\end{array}$ \\
\hline Middle Quintile & $\begin{array}{l}-0.011 \\
(0.024)\end{array}$ & $\begin{array}{l}-0.003 \\
(0.019)\end{array}$ & $\begin{array}{l}-0.010 \\
(0.021)\end{array}$ \\
\hline Second Richest Quintile & $\begin{array}{l}0.037 \\
(0.033)\end{array}$ & $\begin{array}{l}0.027 \\
(0.030)\end{array}$ & $\begin{array}{l}0.027 \\
(0.033)\end{array}$ \\
\hline Richest Quintile & $\begin{array}{l}0.026 \\
(0.039)\end{array}$ & $\begin{array}{l}0.014 \\
(0.032)\end{array}$ & $\begin{array}{l}0.006 \\
(0.037)\end{array}$ \\
\hline Age Bin $2 *$ Second Poorest Quintile & $\begin{array}{l}0.054^{* *} \\
(0.024)\end{array}$ & $\begin{array}{l}0.042^{*} \\
(0.023)\end{array}$ & $\begin{array}{l}0.045 \\
(0.029)\end{array}$ \\
\hline Age Bin 3 *Second Poorest Quintile & $\begin{array}{l}0.078^{* * *} \\
(0.030)\end{array}$ & $\begin{array}{l}0.055^{* *} \\
(0.026)\end{array}$ & $\begin{array}{l}0.038 \\
(0.029)\end{array}$ \\
\hline Age Bin 4 *Second Poorest Quintile & $\begin{array}{l}0.053^{*} \\
(0.029)\end{array}$ & $\begin{array}{l}0.032 \\
(0.027)\end{array}$ & $\begin{array}{l}0.031 \\
(0.033)\end{array}$ \\
\hline Age Bin 5 *Second Poorest Quintile & $\begin{array}{l}0.053 \\
(0.033)\end{array}$ & $\begin{array}{l}0.041 \\
(0.030)\end{array}$ & $\begin{array}{l}0.032 \\
(0.033)\end{array}$ \\
\hline Age Bin 6 *Second Poorest Quintile & $\begin{array}{l}0.062^{*} \\
(0.033)\end{array}$ & $\begin{array}{l}0.030 \\
(0.031)\end{array}$ & $\begin{array}{l}0.030 \\
(0.035)\end{array}$ \\
\hline Age Bin 2 *Middle Quintile & $\begin{array}{l}0.085^{* * * *} \\
(0.025)\end{array}$ & $\begin{array}{l}0.062^{* * *} \\
(0.022)\end{array}$ & $\begin{array}{l}0.054^{* *} \\
(0.025)\end{array}$ \\
\hline Age Bin 3 *Middle Quintile & $\begin{array}{l}0.107 * * * \\
(0.026)\end{array}$ & $\begin{array}{l}0.082^{* * *} \\
(0.022)\end{array}$ & $\begin{array}{l}0.065^{* *} \\
(0.026)\end{array}$ \\
\hline Age Bin 4 *Middle Quintile & $\begin{array}{l}0.092^{* * *} \\
(0.029)\end{array}$ & $\begin{array}{l}0.066^{* * * *} \\
(0.024)\end{array}$ & $\begin{array}{l}0.058^{* *} \\
(0.026)\end{array}$ \\
\hline Age Bin 5 *Middle Quintile & $\begin{array}{l}0.107^{* * * *} \\
(0.030)\end{array}$ & $\begin{array}{l}0.090^{* * *} \\
(0.027)\end{array}$ & $\begin{array}{l}0.081^{* *} \\
(0.032)\end{array}$ \\
\hline Age Bin 6 *Middle Quintile & $\begin{array}{l}0.120^{* * * *} \\
(0.033)\end{array}$ & $\begin{array}{l}0.081^{* * * *} \\
(0.030)\end{array}$ & $\begin{array}{l}0.085^{* *} \\
(0.037)\end{array}$ \\
\hline Age Bin 2 *Second Richest Quintile & $\begin{array}{l}0.064^{*} \\
(0.036)\end{array}$ & $\begin{array}{l}0.046 \\
(0.034)\end{array}$ & $\begin{array}{l}0.027 \\
(0.039)\end{array}$ \\
\hline Age Bin 3 *Second Richest Quintile & $\begin{array}{l}0.119 * * * \\
(0.039)\end{array}$ & $\begin{array}{l}0.086^{* *} \\
(0.035)\end{array}$ & $\begin{array}{l}0.045 \\
(0.039)\end{array}$ \\
\hline Age Bin 4 *Second Richest Quintile & $\begin{array}{l}0.095^{* *} \\
(0.039)\end{array}$ & $\begin{array}{l}0.061^{*} \\
(0.037)\end{array}$ & $\begin{array}{l}0.043 \\
(0.042)\end{array}$ \\
\hline Age Bin 5 *Second Richest Quintile & $\begin{array}{l}0.132 * * * \\
(0.038)\end{array}$ & $\begin{array}{l}0.110^{* * *} \\
(0.036)\end{array}$ & $\begin{array}{l}0.087^{* *} \\
(0.042)\end{array}$ \\
\hline Age Bin 6 *Second Richest Quintile & $\begin{array}{l}0.120^{* * *} \\
(0.042)\end{array}$ & $\begin{array}{l}0.083^{* *} \\
(0.039)\end{array}$ & $\begin{array}{l}0.062 \\
(0.043)\end{array}$ \\
\hline Age Bin $2 *$ Richest Quintile & $\begin{array}{l}0.082^{* *} \\
(0.041)\end{array}$ & $\begin{array}{l}0.066^{*} \\
(0.037)\end{array}$ & $\begin{array}{l}0.053 \\
(0.041)\end{array}$ \\
\hline Age Bin $3 *$ Richest Quintile & $\begin{array}{l}0.157 * * * \\
(0.043)\end{array}$ & $\begin{array}{l}0.119 * * * \\
(0.037)\end{array}$ & $\begin{array}{l}0.077^{*} \\
(0.042)\end{array}$ \\
\hline Age Bin 4 *Richest Quintile & $\begin{array}{l}0.151^{* * *} \\
(0.038)\end{array}$ & $\begin{array}{l}0.104^{* * *} \\
(0.032)\end{array}$ & $\begin{array}{l}0.080^{* *} \\
(0.035)\end{array}$ \\
\hline Age Bin 5 *Richest Quintile & $\begin{array}{l}0.145^{* * * *} \\
(0.040)\end{array}$ & $\begin{array}{l}0.112^{* * * *} \\
(0.034)\end{array}$ & $\begin{array}{l}0.063 \\
(0.039)\end{array}$ \\
\hline Age Bin 6 *Richest Quintile & $\begin{array}{l}0.197 * * * \\
(0.047)\end{array}$ & $\begin{array}{l}0.168^{* * * *} \\
(0.041)\end{array}$ & $\begin{array}{l}0.126^{* * * *} \\
(0.048)\end{array}$ \\
\hline Observations & 50,754 & 50,754 & 38,407 \\
\hline Adjusted $\mathrm{R}^{2}$ & 0.010 & 0.054 & 0.067 \\
\hline Demographic Controls & NO & NO & YES \\
\hline Country FE & NO & YES & YES \\
\hline Countries number & 65 & 65 & 60 \\
\hline
\end{tabular}

Note: ${ }^{*} \mathrm{p}<0.1 ;{ }^{* *} \mathrm{p}<0.05 ;{ }^{* * *} \mathrm{p}<0.01$; Clustered standard errors at country level. 
Table A2

Patience comparison regression. Dependent Variable is patience calculated at the country level (percentage of LL choices on the PELI).

\begin{tabular}{llll}
\hline Dep Var: Patience & $(1)$ & $(2)$ & $(3)$ \\
\hline Patience Falk et al. (2018) & $0.174^{* * *}$ & & $0.118^{* *}$ \\
& $(0.030)$ & & $(0.049)$ \\
Patience Wang et al. (2016) & & $0.271^{* * *}$ & $0.144^{*}$ \\
& & $(0.080)$ & $(0.085)$ \\
Observations & 44 & 28 & 23 \\
Adjusted R & 0.351 & 0.161 & 0.344 \\
\hline
\end{tabular}

Note: ${ }^{*} \mathrm{p}<0.1 ;{ }^{* *} \mathrm{p}<0.05 ;{ }^{* * *} \mathrm{p}<0.01 ;$ Robust Standard Errors in parenthesis

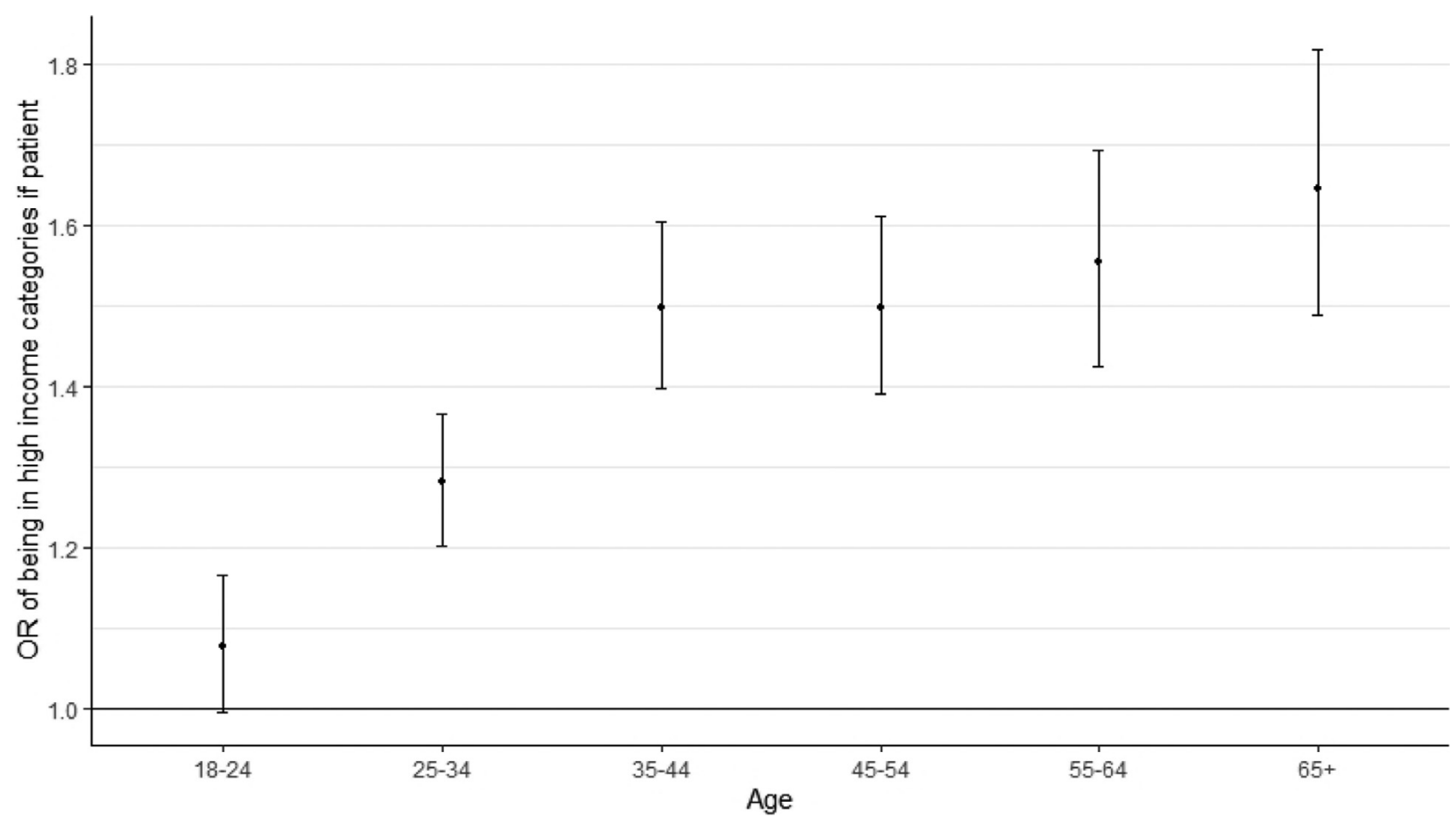

Fig. A2. Odds of high income for patient individuals. The figure plots the odds of the coefficient from six ordinal logistic regressions (for the six age groups) with the income quintile as the dependent variable and a dummy indicating the choice of LL as a regressor (95\% confidence intervals). It shows the odds of being in a higher income quintile instead of a lower income quintile for someone who chooses LL relative to the odds for someone who chooses SS, at each age group.

\section{A.2. Comparison with other established measures}

Table A2 shows the results of three linear regressions where we regress the national PELI (proportion of respondents choosing LL in the country) on the alternative patience indices obtained by Falk et al. (2018) and Wang et al. (2016). They can both explain a lot of the variation in our index, but Falk et al. (2018) is more strongly correlated with our measure. Moreover, even in the small set of countries (23) where all three indices were measured, the correlations are strong.

To compare our results with Epper et al. (2020), we examine how income differs for patient and impatient individuals across income groups. We perform six ordinal logistic regressions (one for each age group) with income quintile as the dependent variable. We include a dummy equal to 1 if the respondent chose LL. Fig. A2 plots the odds of the coefficients from the six regressions. For example, it shows the odds of being in a higher income quintile instead of being in a lower income quintile for someone who chooses LL relative to the odds for someone who chooses SS, at each age group. It confirms that in the youngest group, income quintiles do not vary in patience. The odds ratio grows with age, and for the oldest group, the odds that patient people are in an income quintile greater than the poorest are 1.65 times the corresponding odds for impatient people. To be more precise, for those aged 65 or more the following holds:

$$
\frac{\operatorname{Pr}(\text { Inc. quintile }>\mathrm{j} \text { if LL }) / \operatorname{Pr}(\text { Inc. quintile } \leq \mathrm{j} \text { if LL })}{\operatorname{Pr}(\text { Inc. quintile }>\mathrm{j} \text { if SS }) / \operatorname{Pr}(\text { Inc. quintile } \leq \mathrm{j} \text { if SS })}=1.65 \quad j \in\{1,2,3,4\}
$$


Table A3

Macro areas regressions. Linear probability model. A re-estimate of the regression of patience on income, age and their interactions, controlling for country fixed effects, on four different subsets of the data.

\begin{tabular}{|c|c|c|c|c|}
\hline Dep Var: Larger Later & $\begin{array}{l}\text { Europe } \\
\text { (1) }\end{array}$ & $\begin{array}{l}\text { Americas } \\
(2)\end{array}$ & $\begin{array}{l}\text { Asia Oceania } \\
\text { (3) }\end{array}$ & $\begin{array}{l}\text { MENA Africa } \\
\text { (4) }\end{array}$ \\
\hline Age (decades) & $\begin{array}{l}-0.035^{* * * *} \\
(0.004)\end{array}$ & $\begin{array}{l}-0.016^{* *} \\
(0.007)\end{array}$ & $\begin{array}{l}-0.007 \\
(0.007)\end{array}$ & $\begin{array}{l}-0.025^{* * * *} \\
(0.006)\end{array}$ \\
\hline Second Poorest Quintile & $\begin{array}{l}0.048 \\
(0.031)\end{array}$ & $\begin{array}{l}0.048 \\
(0.043)\end{array}$ & $\begin{array}{l}0.085^{* *} \\
(0.043)\end{array}$ & $\begin{array}{l}-0.067^{*} \\
(0.038)\end{array}$ \\
\hline Middle Quintile & $\begin{array}{l}0.048 \\
(0.030)\end{array}$ & $\begin{array}{l}0.027 \\
(0.044)\end{array}$ & $\begin{array}{l}0.020 \\
(0.041)\end{array}$ & $\begin{array}{l}-0.068^{*} \\
(0.039)\end{array}$ \\
\hline Second Richest Quintile & $\begin{array}{l}0.065^{* *} \\
(0.032)\end{array}$ & $\begin{array}{l}0.037 \\
(0.051)\end{array}$ & $\begin{array}{l}-0.014 \\
(0.045)\end{array}$ & $\begin{array}{l}0.029 \\
(0.046)\end{array}$ \\
\hline Richest Quintile & $\begin{array}{l}0.054 \\
(0.036)\end{array}$ & $\begin{array}{l}-0.003 \\
(0.058)\end{array}$ & $\begin{array}{l}0.042 \\
(0.049)\end{array}$ & $\begin{array}{l}-0.120^{* *} \\
(0.061)\end{array}$ \\
\hline Age (decades) *Second Poorest Q. & $\begin{array}{l}-0.002 \\
(0.006)\end{array}$ & $\begin{array}{l}-0.0002 \\
(0.009)\end{array}$ & $\begin{array}{l}-0.010 \\
(0.010)\end{array}$ & $\begin{array}{l}0.022^{* *} \\
(0.009)\end{array}$ \\
\hline Age (decades) *Middle $\mathrm{Q}$. & $\begin{array}{l}0.006 \\
(0.006)\end{array}$ & $\begin{array}{l}0.012 \\
(0.010)\end{array}$ & $\begin{array}{l}0.008 \\
(0.010)\end{array}$ & $\begin{array}{l}0.025^{* * * *} \\
(0.010)\end{array}$ \\
\hline Age (decades) *Second Richest Q. & $\begin{array}{l}0.013^{*} \\
(0.007)\end{array}$ & $\begin{array}{l}0.011 \\
(0.011)\end{array}$ & $\begin{array}{l}0.017 \\
(0.011)\end{array}$ & $\begin{array}{l}0.009 \\
(0.011)\end{array}$ \\
\hline Age (decades) *Richest $\mathrm{Q}$. & $\begin{array}{l}0.020^{* * *} \\
(0.007)\end{array}$ & $\begin{array}{l}0.026^{* *} \\
(0.013)\end{array}$ & $\begin{array}{l}0.007 \\
(0.011)\end{array}$ & $\begin{array}{l}0.045^{* * *} \\
(0.015)\end{array}$ \\
\hline Observations & 20,236 & 8,657 & 11,772 & 10,089 \\
\hline $\mathrm{R}^{2}$ & 0.072 & 0.062 & 0.025 & 0.039 \\
\hline Adjusted $R^{2}$ & 0.071 & 0.060 & 0.023 & 0.037 \\
\hline Country FE & YES & YES & YES & YES \\
\hline
\end{tabular}

Note: ${ }^{*} \mathrm{p}<0.1 ;{ }^{* *} \mathrm{p}<0.05 ;{ }^{* * *} \mathrm{p}<0.01$; Robust standard errors.

Simply put, the income gap between patient and impatient individuals grows with age. This is largely consistent with Epper et al. (2020).

\section{A.3. Region-specific analysis}

We repeat the regression from Equation (1) of patience on income, age and their interactions, controlling for country fixed effects, each time restricting the analysis to a single macro area, as classified by Gallup (Table A3). The qualitative results regarding the relationship between age, income, and patience are consistent within all macro areas except the Asia/Oceania area, where no effect was found. Future research might explore why the relationship fails to hold in this region.

\section{A.4. Cultural clusters analysis}

We repeat the regression from Equation (1) of patience on income, age and their interactions, controlling for country fixed effects, restricting to a single cultural cluster each time (Wang et al., 2016; Chhokar et al., 2008). Table A4 contains the regressions corresponding to the predictions reported in Figs. 4 and 5. As discussed in Section 5, the interaction effect is strongest in the Germanic/Nordic and the Anglo/American clusters. However, the direction of the coefficients is broadly consistent with the main divergence pattern, with patience decreasing with age more for the poor than for the rich. Carving up the data like this, however, means that in many cells there are few observations.

In some areas, for some income groups, we detect non-linearities in the relation between age and patience. Figs. A3 and A4 mirror Fig. A1. Those are predictions obtained from running the regression from Equation (1) in the eight cultural clusters. In the Germanic/Nordic and in the Anglo/American clusters a linear trend well approximates the relation between age and patience in all income groups. Some noteworthy non-linearities are present in other groups for some income cells, but in some cases not many observations are present in an income/age/cultural cluster combination.

\section{A.5. Questions}

- As far as you are concerned, do you think that 2016 will be better, worse or the same than 2015? (Dummy equal to 1 if Better)

- Better

- Worse

- Same 
Table A4

Patience by cultural cluster. Linear probability model. A re-estimate of the regression of patience on income, age and their interactions, controlling for country fixed effects. We group the countries into eight cultural clusters based on Chhokar et al. (2008).

\begin{tabular}{|c|c|c|c|c|c|c|c|c|}
\hline Dep Var: Larger Later & $\begin{array}{l}\text { Ger/Nor } \\
\text { (1) }\end{array}$ & $\begin{array}{l}\text { Anglo/Am } \\
\text { (2) }\end{array}$ & $\begin{array}{l}\text { Asia } \\
(3)\end{array}$ & $\begin{array}{l}\text { Lat Eur } \\
(4)\end{array}$ & $\begin{array}{l}\text { East Eur } \\
\text { (5) }\end{array}$ & $\begin{array}{l}\text { LATAM } \\
(6)\end{array}$ & $\begin{array}{l}\text { Mid East } \\
\text { (7) }\end{array}$ & $\begin{array}{l}\text { Africa } \\
(8)\end{array}$ \\
\hline Age (in decades) & $\begin{array}{l}-0.061 \text { **** } \\
(0.009)\end{array}$ & $\begin{array}{l}-0.022^{* *} \\
(0.010)\end{array}$ & $\begin{array}{l}0.001 \\
(0.008)\end{array}$ & $\begin{array}{l}-0.024^{*} * \\
(0.012)\end{array}$ & $\begin{array}{l}-0.029^{* * * *} \\
(0.006)\end{array}$ & $\begin{array}{l}-0.010 \\
(0.008)\end{array}$ & $\begin{array}{l}-0.032^{* * * *} \\
(0.010)\end{array}$ & $\begin{array}{l}-0.025^{\text {**** }} \\
(0.009)\end{array}$ \\
\hline Second Poorest Quintile & $\begin{array}{l}-0.023 \\
(0.059)\end{array}$ & $\begin{array}{l}-0.034 \\
(0.067)\end{array}$ & $\begin{array}{l}0.085^{*} \\
(0.044)\end{array}$ & $\begin{array}{l}0.122 \\
(0.081)\end{array}$ & $\begin{array}{l}0.052 \\
(0.044)\end{array}$ & $\begin{array}{l}0.086^{*} \\
(0.047)\end{array}$ & $\begin{array}{l}-0.066 \\
(0.056)\end{array}$ & $\begin{array}{l}-0.192^{* * *} \\
(0.067)\end{array}$ \\
\hline Middle Richest Quintile & $\begin{array}{l}0.057 \\
(0.058)\end{array}$ & $\begin{array}{l}-0.051 \\
(0.065)\end{array}$ & $\begin{array}{l}0.036 \\
(0.042)\end{array}$ & $\begin{array}{l}0.211^{\text {**** }} \\
(0.076)\end{array}$ & $\begin{array}{l}0.006 \\
(0.043)\end{array}$ & $\begin{array}{l}0.068 \\
(0.049)\end{array}$ & $\begin{array}{l}-0.088 \\
(0.057)\end{array}$ & $\begin{array}{l}-0.034 \\
(0.065)\end{array}$ \\
\hline Second Richest Quintile & $\begin{array}{l}0.038 \\
(0.062)\end{array}$ & $\begin{array}{l}0.003 \\
(0.068)\end{array}$ & $\begin{array}{l}0.027 \\
(0.046)\end{array}$ & $\begin{array}{l}0.181^{* *} \\
(0.084)\end{array}$ & $\begin{array}{l}0.067 \\
(0.048)\end{array}$ & $\begin{array}{l}0.086 \\
(0.056)\end{array}$ & $\begin{array}{l}0.010 \\
(0.062)\end{array}$ & $\begin{array}{l}0.009 \\
(0.096)\end{array}$ \\
\hline Richest Quintile & $\begin{array}{l}0.042 \\
(0.066)\end{array}$ & $\begin{array}{l}0.030 \\
(0.075)\end{array}$ & $\begin{array}{l}0.073 \\
(0.051)\end{array}$ & $\begin{array}{l}0.096 \\
(0.089)\end{array}$ & $\begin{array}{l}0.050 \\
(0.054)\end{array}$ & $\begin{array}{l}0.045 \\
(0.067)\end{array}$ & $\begin{array}{l}-0.220^{* * * *} \\
(0.078)\end{array}$ & $\begin{array}{l}-0.0002 \\
(0.115)\end{array}$ \\
\hline Age *Second Poorest Quintile & $\begin{array}{l}0.018 \\
(0.012)\end{array}$ & $\begin{array}{l}0.010 \\
(0.013)\end{array}$ & $\begin{array}{l}-0.008 \\
(0.011)\end{array}$ & $\begin{array}{l}-0.011 \\
(0.016)\end{array}$ & $\begin{array}{l}-0.002 \\
(0.009)\end{array}$ & $\begin{array}{l}-0.012 \\
(0.010)\end{array}$ & $\begin{array}{l}0.023^{*} \\
(0.014)\end{array}$ & $\begin{array}{l}0.055^{* * * *} \\
(0.018)\end{array}$ \\
\hline Age *Middle Richest Quintile & $\begin{array}{l}0.014 \\
(0.012)\end{array}$ & $\begin{array}{l}0.027^{* *} \\
(0.013)\end{array}$ & $\begin{array}{l}0.004 \\
(0.010)\end{array}$ & $\begin{array}{l}-0.021 \\
(0.015)\end{array}$ & $\begin{array}{l}0.011 \\
(0.009)\end{array}$ & $\begin{array}{l}-0.001 \\
(0.011)\end{array}$ & $\begin{array}{l}0.028^{*} \\
(0.015)\end{array}$ & $\begin{array}{l}0.021 \\
(0.017)\end{array}$ \\
\hline Age *Second Richest Quintile & $\begin{array}{l}0.029^{* *} \\
(0.013)\end{array}$ & $\begin{array}{l}0.027^{* *} \\
(0.013)\end{array}$ & $\begin{array}{l}0.004 \\
(0.011)\end{array}$ & $\begin{array}{l}-0.010 \\
(0.017)\end{array}$ & $\begin{array}{l}0.009 \\
(0.010)\end{array}$ & $\begin{array}{l}-0.009 \\
(0.013)\end{array}$ & $\begin{array}{l}0.014 \\
(0.016)\end{array}$ & $\begin{array}{l}0.011 \\
(0.024)\end{array}$ \\
\hline Age *Richest Quintile & $\begin{array}{l}0.032^{* *} \\
(0.013)\end{array}$ & $\begin{array}{l}0.029^{*} \\
(0.015)\end{array}$ & $\begin{array}{l}-0.002 \\
(0.012)\end{array}$ & $\begin{array}{l}0.004 \\
(0.018)\end{array}$ & $\begin{array}{l}0.018 \\
(0.012)\end{array}$ & $\begin{array}{l}0.003 \\
(0.016)\end{array}$ & $\begin{array}{l}0.064^{* * *} \\
(0.020)\end{array}$ & $\begin{array}{l}0.031 \\
(0.029)\end{array}$ \\
\hline Constant & $\begin{array}{l}0.835^{* * *} \\
(0.043)\end{array}$ & $\begin{array}{l}0.594^{* * * *} \\
(0.053)\end{array}$ & $\begin{array}{l}0.358^{* * * *} \\
(0.034)\end{array}$ & $\begin{array}{l}0.510^{* * * *} \\
(0.062)\end{array}$ & $\begin{array}{l}0.481^{\text {**** }} \\
(0.035)\end{array}$ & $\begin{array}{l}0.468^{* * * *} \\
(0.042)\end{array}$ & $\begin{array}{l}0.595^{* * *} \\
(0.050)\end{array}$ & $\begin{array}{l}0.478^{* * * *} \\
(0.038)\end{array}$ \\
\hline Obsel & 5,506 & 5,160 & 11,295 & 3,523 & 9,510 & 7,025 & 5,581 & 3,154 \\
\hline Adjusted $\mathrm{R}^{2}$ & 0.047 & 0.031 & 0.021 & 0.033 & 0.047 & 0.054 & 0.056 & 0.005 \\
\hline Country FE & YES & YES & YES & YES & YES & YES & YES & YES \\
\hline
\end{tabular}

Note: ${ }^{*} \mathrm{p}<0.1 ;{ }^{* *} \mathrm{p}<0.05 ;{ }^{* * *} \mathrm{p}<0.01$; Robust standard errors.
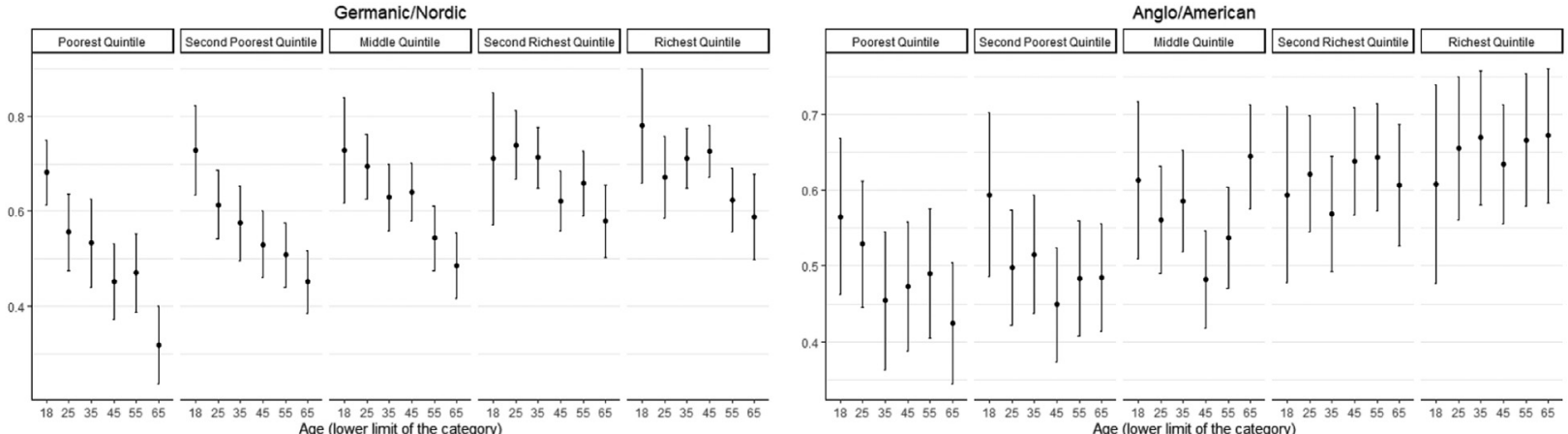

Asia
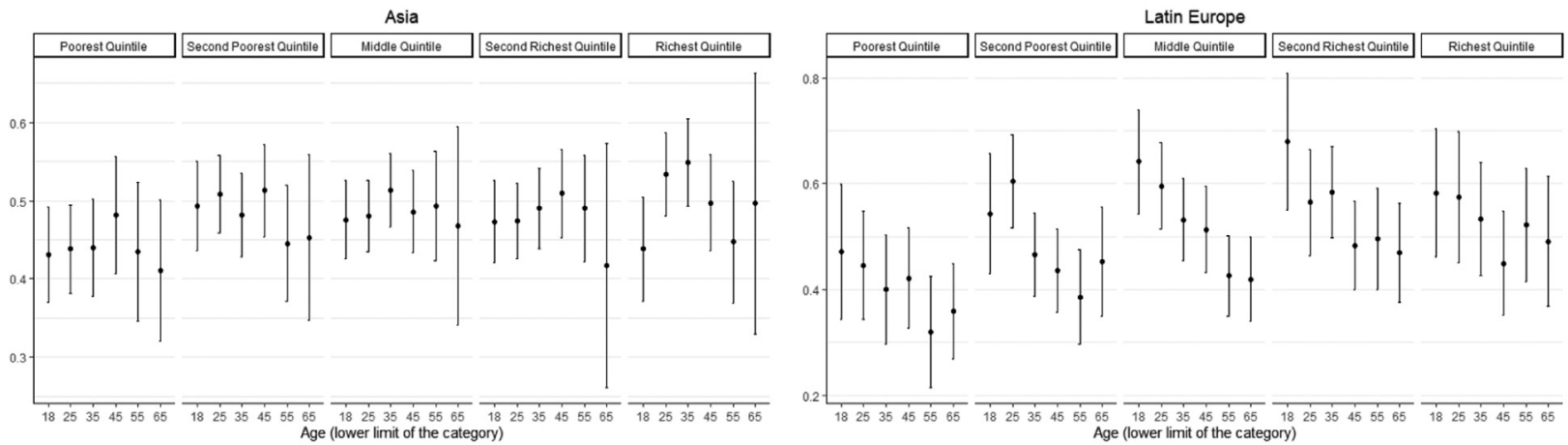

Fig. A3. Probability of choosing LL (patience) by age, income and cultural cluster. Estimated probability of choosing LL for each quintile of income. Predictions based on OLS regression with country fixed effects and clustered standard errors at country level (95\% confidence intervals). Country fixed to: Germany (Germanic/Nordic), the United States of America (Anglo/American), China (Asia) and France (Latin Europe). Age and income are both categorical variables. 

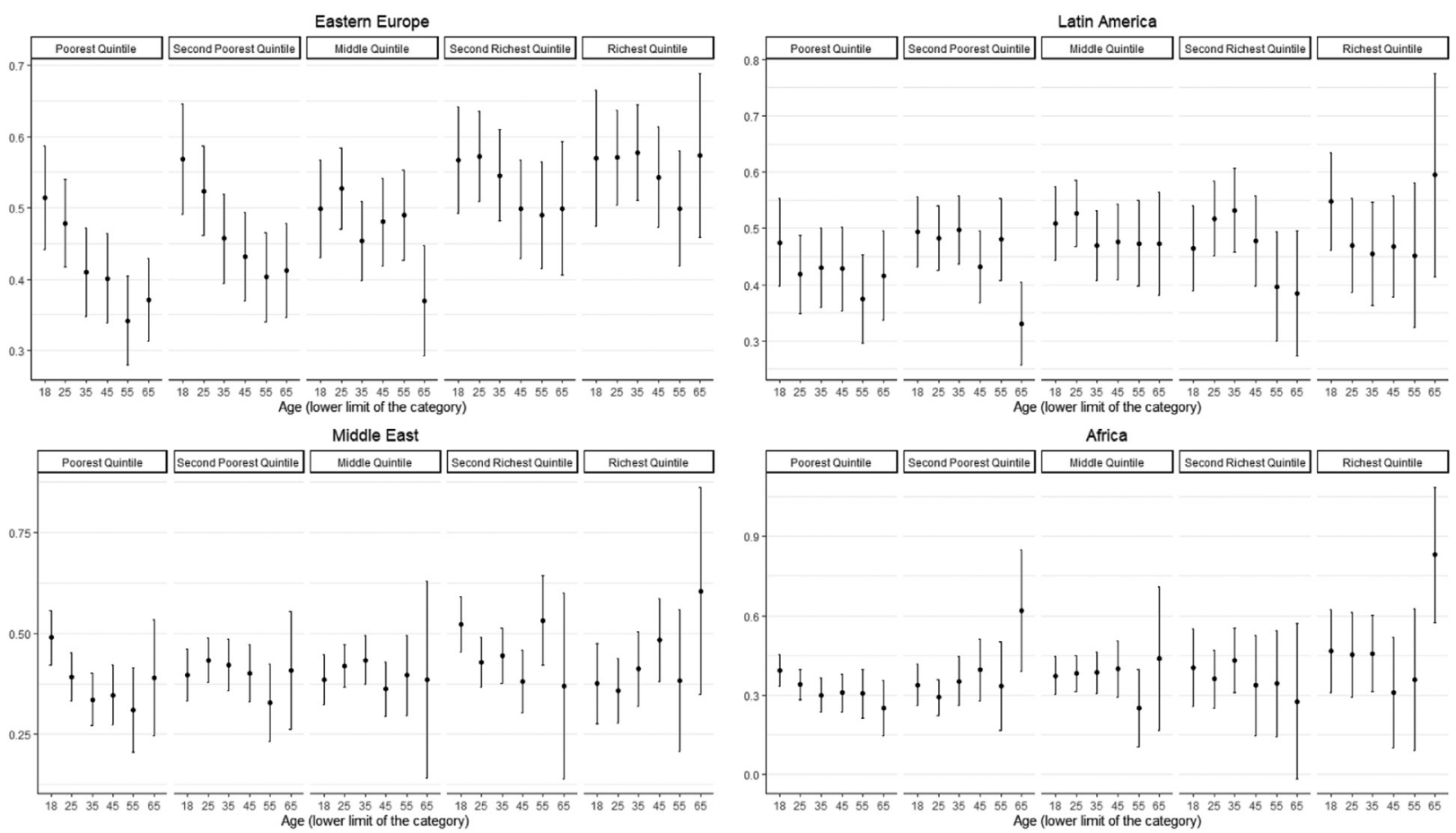

Fig. A4. Probability of choosing LL (patience) by age, income and cultural cluster. Estimated probability of choosing LL for each quintile of income. Predictions based on OLS regression with country fixed effects and clustered standard errors at country level (95\% confidence intervals). Country fixed to: Poland (Eastern Europe), Argentina (Latin America), Lebanon (Middle East) and Ethiopia (Africa).

- Compared to this year, in your opinion, will next year be a year of economic prosperity, economic difficulty or remain the same for your country? ( 1 if Economic prosperity)

- Economic prosperity

- Economic difficulty

- Remain the same

- In general, do you personally feel very happy, happy, neither happy nor unhappy, unhappy or very unhappy about your life? ( 1 if happy or very happy)

- Very happy

- Happy

- Neither happy nor unhappy

- Unhappy

- Very unhappy

- In your opinion, how soon does your country need to change to be a better place? ( 1 if now or short term)

- Never need to change

- In the long term

- In the medium term

- In the short term

- Right now

- Think about your current household income: which of the following choices would you choose if offered?

- A 50/50 chance to receive double your household income

- A guaranteed increase in your household income of $50 \%$

- Again, think about your current household income: which of the following choices would you choose if offered?

- Today you receive an extra payment which is equal to that of your normal monthly income

- In exactly one year from now you receive an extra payment equal to twice that of your normal monthly income 
Table A5

Future Time Reference classification of languages.

\begin{tabular}{|c|c|c|c|}
\hline Country & FTR & Country & FTR \\
\hline Afghanistan & & Japan & $\mathrm{W}$ \\
\hline Algeria & $\mathrm{s}$ & Kosovo & $\mathrm{s}$ \\
\hline Argentina & $\mathrm{s}$ & Latvia & $\mathrm{S}$ \\
\hline Armenia & $\mathrm{S}$ & Lebanon & $\mathrm{S}$ \\
\hline Australia & $\mathrm{s}$ & Macedonia & S \\
\hline Austria & W & Mexico & $\mathrm{s}$ \\
\hline Azerbaijan & $\mathrm{s}$ & Mongolia & \\
\hline Bangladesh & $\mathrm{s}$ & Morocco & $\mathrm{s}$ \\
\hline Belgium & W & Netherlands & W \\
\hline Bosnia Herzegovina & $\mathrm{s}$ & Nigeria & $\mathrm{S}$ \\
\hline Brazil & W & Pakistan & S \\
\hline Bulgaria & $\mathrm{s}$ & Palestine (W Bank Gaza) & $\mathrm{s}$ \\
\hline Canada & $\mathrm{s}$ & Panama & $\mathrm{s}$ \\
\hline China & W & Papua New Guinea & \\
\hline Colombia & $\mathrm{S}$ & Peru & S \\
\hline DR Congo & $\mathrm{s}$ & Philippines & $\mathrm{s}$ \\
\hline Czech Republic & $\mathrm{s}$ & Poland & $\mathrm{S}$ \\
\hline Ecuador & $\mathrm{s}$ & Portugal & $\mathrm{s}$ \\
\hline Ethiopia & W & Russia & $\mathrm{s}$ \\
\hline Fiji & $\mathrm{s}$ & Saudi Arabia & $\mathrm{S}$ \\
\hline Finland & W & Serbia & $\mathrm{s}$ \\
\hline France & S & Slovenia & $\mathrm{s}$ \\
\hline Germany & W & South Africa & $\mathrm{s}$ \\
\hline Ghana & $\mathrm{s}$ & Spain & $\mathrm{S}$ \\
\hline Greece & $\mathrm{s}$ & Sweden & W \\
\hline Hong Kong & W & Thailand & $\mathrm{s}$ \\
\hline Iceland & W & Tunisia & $\mathrm{s}$ \\
\hline India & $\mathrm{S}$ & Turkey & S \\
\hline Indonesia & W & Ukraine & $\mathrm{s}$ \\
\hline Iran & & United Kingdom & $\mathrm{s}$ \\
\hline Iraq & $\mathrm{s}$ & United States & $\mathrm{S}$ \\
\hline Ireland & S & Vietnam & $S$ \\
\hline Italy & S & & \\
\hline
\end{tabular}

- Do you consider yourself:

- Roman Catholic

- Russian or Eastern Orthodox

- Protestant

- Other Christian

- Hindu

- Muslim

- Jewish

- Buddhist

- Other

- Atheist/agnostic

\section{A.6. Language classification (Future Time Reference) \& country cultural classification}

In Table A5 we report the classification of FTR for the countries in our sample. We only included countries whose languages were classified by Chen (2013) or Falk et al. (2018). We did not autonomously classify any languages. In multilingual countries, we classified the country according to the most widely spoken language.

In Table A6 we report the classification of countries in cultural clusters following Chhokar et al. (2008) and Wang et al. (2016). We refer to the GLOBE project for the original classification. We autonomously classified the countries which were not included in the GLOBE cultural clustering. For countries which could be classified in two different cultural groups, we picked one. Wang et al. (2016) did not need to classify countries since they directly asked participants to self-classify themselves into the most appropriate cultural group. 
Table A6

Cultural cluster classification of countries.

\begin{tabular}{|c|c|c|c|}
\hline Country & Cultural Cluster & Country & Cultural Cluster \\
\hline Afghanistan & Asia & Japan & Asia \\
\hline Algeria & Middle East & Kosovo & Eastern Europe \\
\hline Argentina & Latin America & Latvia & Eastern Europe \\
\hline Armenia & Eastern Europe & Lebanon & Middle East \\
\hline Australia & Anglo/American & Macedonia & Eastern Europe \\
\hline Austria & Germanic/Nordic & Mexico & Latin America \\
\hline Azerbaijan & Eastern Europe & Mongolia & Asia \\
\hline Bangladesh & Asia & Morocco & Middle East \\
\hline Belgium & Germanic/Nordic & Netherlands & Germanic/Nordic \\
\hline Bosnia Herzegovina & Eastern Europe & Nigeria & Africa \\
\hline Brazil & Latin America & Pakistan & Asia \\
\hline Bulgaria & Eastern Europe & Palestine (W Bank Gaza) & Middle East \\
\hline Canada & Anglo/American & Panama & Latin America \\
\hline China & Asia & Papua New Guinea & Africa \\
\hline Colombia & Latin America & Peru & Latin America \\
\hline DR Congo & Africa & Philippines & Asia \\
\hline Czech Republic & Eastern Europe & Poland & Eastern Europe \\
\hline Ecuador & Latin America & Portugal & Latin Europe \\
\hline Ethiopia & Africa & Russia & Eastern Europe \\
\hline Fiji & Asia & Saudi Arabia & Middle East \\
\hline Finland & Germanic/Nordic & Serbia & Eastern Europe \\
\hline France & Latin Europe & Slovenia & Eastern Europe \\
\hline Germany & Germanic/Nordic & South Africa & Anglo/American \\
\hline Ghana & Africa & Spain & Latin Europe \\
\hline Greece & Eastern Europe & Sweden & Nordic/Germanic \\
\hline Hong Kong & Asia & Thailand & Asia \\
\hline Iceland & Nordic/Germanic & Tunisia & Middle East \\
\hline India & Asia & Turkey & Middle East \\
\hline Indonesia & Asia & Ukraine & Eastern Europe \\
\hline Iran & Asia & United Kingdom & Anglo/American \\
\hline Iraq & Middle East & United States & Anglo/American \\
\hline Ireland & Anglo/American & Vietnam & Asia \\
\hline Italy & Latin Europe & & \\
\hline
\end{tabular}

\section{References}

Ai, C., Norton, E.C., 2003. Interaction terms in logit and probit models. Economics Letters 80 (1), 123-129.

Alesina, A., Giuliano, P., 2014. Family ties. In: Aghion, P., Durlauf, S.N. (Eds.), Handbook of Economic Growth, Vol. 2. Elsevier, pp. 177-215.

Anderhub, V., Güth, W., Gneezy, U., Sonsino, D., 2001. On the interaction of risk and time preferences: An experimental study. German Economic Review 2 (3), 239-253.

Andreoni, J., Gravert, C., Kuhn, M.A., Saccardo, S., Yang, Y., 2018. Arbitrage or narrow bracketing? on using money to measure intertemporal preferences. National Bureau of Economic Research.

Bartoš, V., Bauer, M., Chytilová, J., Levely, I., 2021. Psychological effects of poverty on time preferences. The Economic Journal 131 (638), $2357-2382$.

Bauer, M., Chytilová, J., 2013. Women, children and patience: Experimental evidence from Indian villages. Review of Development Economics 17 (4), 662-675.

Becker, G.S., 1962. Investment in human capital: A theoretical analysis. Journal of Political Economy 70 (5), 9-49.

Becker, G.S., Mulligan, C.B., 1997. The endogenous determination of time preference. The Quarterly Journal of Economics 112 (3), $729-758$.

Ben-Porath, Y., 1967. The production of human capital and the life cycle of earnings. Journal of Political Economy 75 (4), $352-365$.

Bickel, W.K., Moody, L.N., Higgins, S.T., 2016. Some current dimensions of the behavioral economics of health-related behavior change. Preventive medicine 92, 16-23.

Breuer, W., Renerken, T., Salzmann, A.J., 2020. On the measurement of risk-taking and patience in financial decision-making. SSRN 2538482.

Bruderer Enzler, H., Diekmann, A., Meyer, R., 2014. Subjective discount rates in the general population and their predictive power for energy saving behavior. Energy Policy 65 (C), 524-540.

Bucher-Koenen, T., Lusardi, A., 2011. Financial literacy and retirement planning in germany. Journal of Pension Economics and Finance 10 (4), 565-584.

Bulley, A., Pepper, G.V., 2017. Cross-country relationships between life expectancy, intertemporal choice and age at first birth. Evolution and Human Behavior 38 (5), 652-658.

Chabris, C.F., Laibson, D., Morris, C.L., Schuldt, J.P., Taubinsky, D., 2008. Individual laboratory-measured discount rates predict field behavior. Journal of Risk and Uncertainty $37(2-3), 237$.

Chao, L.-W., Szrek, H., Sousa Pereira, N., Pauly, M.V., 2009. Time preference and its relationship with age, health, and survival probability. Judgment and Decision Making 4 (1), 1-19.

Chen, K.M., 2013. The effect of language on economic behavior: Evidence from savings rates, health behaviors, and retirement assets. American Economic Review 103 (2), 690-731.

Chetty, R., Stepner, M., Abraham, S., Lin, S., Scuderi, B., Turner, N., Bergeron, A., Cutler, D., 2016. The Association Between Income and Life Expectancy in the United States, 2001-2014. JAMA 315 (16), 1750-1766.

Chhokar, J.S., Brodbeck, F.C., House, R.J., 2008. Culture and leadership across the world: The GLOBE book of in-depth studies of 25 societies. Routledge.

Chu, C.C., Chien, H.-K., Lee, R.D., 2010. The evolutionary theory of time preferences and intergenerational transfers. Journal of Economic Behavior \& Organization 76 (3), 451-464.

Cohen, J., Ericson, K.M., Laibson, D., White, J.M., 2020. Measuring time preferences. Journal of Economic Literature 58 (2), $299-347$.

Cropper, M.L., Aydede, S.K., Portney, P.R., 1994. Preferences for life saving programs: How the public discounts time and age. Journal of Risk and Uncertainty 8 (3), 243-265. 
Cubitt, R.P., Read, D., 2007. Can intertemporal choice experiments elicit time preferences for consumption? Experimental Economics 10 (4), 369-389.

Diamond, J.M., 2005. Guns, germs and steel: a short history of everybody for the last 13,000 years. National Geographic, Washington, D.C..

Dittrich, M., Leipold, K., 2014. Gender differences in time preferences. Economics Letters 122 (3), 413-415.

Doepke, M., Zilibotti, F., 2008. Occupational choice and the spirit of capitalism. The Quarterly Journal of Economics 123 (2), $747-793$.

Dohmen, T., Enke, B., Falk, A., Huffman, D., Sunde, U., 2018. Patience and comparative development. Working Paper.

Du, W., Green, L., Myerson, J., 2002. Cross-cultural comparisons of discounting delayed and probabilistic rewards. The Psychological Record 52 (4), 479-492.

Epper, T., Fehr, E., Fehr-Duda, H., Kreiner, C.T., Lassen, D.D., Leth-Petersen, S., Rasmussen, G.N., 2020. Time discounting and wealth inequality. American Economic Review 110 (4), 1177-1205.

Eppinger, B., Heekeren, H.R., Li, S.-C., 2017. Age differences in the neural mechanisms of intertemporal choice under subjective decision conflict. Cerebral Cortex 28 (11), 3764-3774.

Falk, A., Becker, A., Dohmen, T., Enke, B., Huffman, D., Sunde, U., 2018. Global evidence on economic preferences. The Quarterly Journal of Economics 133 (4), 1645-1692.

Falk, A., Becker, A., Dohmen, T., Huffman, D., Sunde, U., 2016. The preference survey module: A validated instrument for measuring risk, time, and social preferences. IZA Discussion Paper No. 9674.

Falk, A., Hermle, J., Sunde, U., 2019. Longevity and Patience. Discussion Paper.

Ferecatu, A., Önçüler, A., 2016. Heterogeneous risk and time preferences. Journal of Risk and Uncertainty 53 (1), 1-28.

Fisher, I., 1930. The theory of interest, as determined by impatience to spend income and opportunity to invest it. Macmillan.

Frederick, S., 2005. Cognitive reflection and decision making. Journal of Economic perspectives 19 (4), $25-42$.

Galor, O., Özak, O., 2016. The agricultural origins of time preference. American Economic Review 106 (10), $3064-3103$.

Graham, R.J., 1981. The role of perception of time in consumer research. Journal of Consumer Research 7 (4), 335-342.

Green, L., Myerson, J., 2004. A discounting framework for choice with delayed and probabilistic rewards. Psychological Bulletin 130 (5), $769-792$.

Green, L., Myerson, J., Lichtman, D., Rosen, S., Fry, A., 1996. Temporal discounting in choice between delayed rewards: the role of age and income. Psychology and aging 11 (1), 79-84.

Green, L., Myerson, J., Mcfadden, E., 1997. Rate of temporal discounting decreases with amount of reward. Memory and Cognition 25, 715-723.

Green, L., Myerson, J., Ostaszewski, P., 1999. Discounting of delayed rewards across the life span: age differences in individual discounting functions. Behavioural Processes 46 (1), 89-96.

Harrison, G.W., Lau, M.I., Williams, M.B., 2002. Estimating individual discount rates in denmark: A field experiment. American Economic Review 92 (5), $1606-1617$.

Haushofer, J., Fehr, E., 2019. Negative income shocks increase discount rates. Working Paper.

Hausman, J.A., 1979. Individual discount rates and the purchase and utilization of energy-using durables. Bell Journal of Economics 10 (1), 33-54.

Henrich, J. Heine, S.J. Norenzayan, A. 2010. Beyond weird: Towards a broad-based behavioral science. Behavioral and Brain Sciences 33 (2-3), 111.

Hofstede, G., 2001. Culture's Consequences: Comparing Values, Behaviors, Institutions, and Organizations Across Nations. Sage, Thousand Oaks, CA.

Hofstede, G., Bond, M.H., 1988. The confucius connection: From cultural roots to economic growth. Organizational dynamics 16 (4), 5-21.

Huffman, D., Maurer, R., Mitchell, O.S., 2019. Time discounting and economic decision-making in the older population. The Journal of the Economics of Ageing 14, 100-121.

Ifcher, J., Zarghamee, H., 2011. Happiness and time preference: The effect of positive affect in a random-assignment experiment. American Economic Review 101 (7), 3109-3129.

Kirby, K.N., Godoy, R., Reyes-García, V., Byron, E., Apaza, L., Leonard, W., Pérez, E., Vadez, V., Wilkie, D., 2002. Correlates of delay-discount rates: Evidence from tsimane' amerindians of the bolivian rain forest. Journal of Economic Psychology 23 (3), 291-316.

Lahav, E., Benzion, U., Shavit, T., 2010. Subjective time discount rates among teenagers and adults: Evidence from israel. The Journal of Socio-Economics 39 (4), 458-465.

Lawrance, E.C., 1991. Poverty and the rate of time preference: Evidence from panel data. Journal of Political Economy 99 (1), $54-77$.

Löckenhoff, C.E., O’Donoghue, T., Dunning, D., 2011. Age differences in temporal discounting: The role of dispositional affect and anticipated emotions. Psychology and Aging 26 (2), 274-284.

Loewenstein, G., 1992. othe fall and rise of psychological explanations in the economics of intertemporal choice. Choice over Time, New York: Russel Sage Foundation 3034 .

Loibl, C., 2017. Living in Poverty: Understanding the Financial Behaviour of Vulnerable Groups. John Wiley \& Sons, Ltd, pp. $421-434$.

Macchia, L., Plagnol, A.C., Reimers, S., 2018. Does experience with high inflation affect intertemporal decision making? Sensitivity to inflation rates in argentine and british delay discounting choices. Journal of Behavioral and Experimental Economics 75, 76-83.

Madden, G.J., Bickel, W.K., 2010. Impulsivity: The behavioral and neurological science of discounting. American Psychological Association.

Mahajna, A., Benzion, U., Bogaire, R., Shavit, T., 2008. Subjective discount rates among israeli arabs and israeli jews. The Journal of Socio-Economics 37 (6), $2513-2522$.

Mani, A., Mullainathan, S., Shafir, E., Zhao, J., 2013. Poverty impedes cognitive function. Science 341, 976-980.

Meier, S., Sprenger, C., 2010. Present-biased preferences and credit card borrowing. American Economic Journal: Applied Economics 2 (1), $193-210$.

Meissner, T., Gassmann, X., Faure, C., Schleich, J., 2020. Individual characteristics associated with risk and time preferences - A multi-country representative survey. Working paper.

Mischel, W., Shoda, Y., Rodriguez, M.I., 1989. Delay of gratification in children. Science 244 (4907), 933-938.

Nuscheler, R., Roeder, K., 2016. To vaccinate or to procrastinate? that is the prevention question. Health economics 25 (12), $1560-1581$.

Olsson, O., Hibbs, D., 2005. Biogeography and long-run economic development. European Economic Review 49 (4), $909-938$.

Perez-Arce, F., 2017. The effect of education on time preferences. Economics of Education Review 56, 52-64.

Poulos, C., Whittington, D., 2000. Time preferences for life-saving programs: Evidence from six less developed countries. Environmental Science \& Technology $34(8), 1445-1455$.

Preis, T., Moat, H.S., Stanley, H.E., Bishop, S.R., 2012. Quantifying the advantage of looking forward. Scientific reports 2 , 350.

Ramsey, F.P., 1928. A mathematical theory of saving. The Economic Journal 38 (152), 543-559.

Read, D., Loewenstein, G., Rabin, M., 1999. Choice bracketing. Journal of Risk and Uncertainty 19 (171), 171-197.

Read, D., Read, N., 2004. Time discounting over the lifespan. Organizational Behavior and Human Decision Processes 94 (1), 22-32.

Reimers, S., Maylor, E.A., Stewart, N., Chater, N., 2009. Associations between a one-shot delay discounting measure and age, income, education and realworld impulsive behavior. Personality and Individual Differences 47 (8), 973-978.

Richter, D., Mata, R., 2018. Age differences in intertemporal choice: U-shaped associations in a probability sample of german households. Psychology and Aging 33 (5), 782.

Rieger, M., Wang, M., Hens, T., 2021. Universal time preference. PLOS ONE 16 (2), 1-15.

Rogers, A.R., 1994. Evolution of time preference by natural selection. American Economic Review 460-481.

van Rooij, M., Lusardi, A., Alessie, R., 2011. Financial literacy and stock market participation. Journal of Financial Economics 101 (2), $449-472$.

Seaman, K., Abiodun, S., Fenn, Z., Samanez-Larkin, G., Mata, R., 2020. Temporal discounting across adulthood: A systematic review and meta-analysis.

Sarid, A., Galor, O., 2017. Geographical origins and economic consequences of language structures. Working Paper.

Seaman, K., Gorlick, M., Vekaria, K., Hsu, M., Zald, D., Samanez-Larkin, G., 2016. Adult age differences in decision making across domains: Increased discounting of social and health-related rewards. Psychology and Aging 31, 737-746.

Silverman, I.W., 2003. Gender differences in delay of gratification: A meta-analysis. Sex Roles 49 (9-10), 451-463. 
Sozou, P.D., Seymour, R.M., 2003. Augmented discounting: Interaction between ageing and time-preference behaviour. Proceedings: Biological Sciences 270 (1519), 1047-1053.

Sparrow, E.P., Spaniol, J., 2018. Aging and altruism in intertemporal choice. Psychology and Aging 33 (2), $315-324$.

Spolaore, E., Wacziarg, R., 2013. How deep are the roots of economic development? Journal of Economic Literature 51 (2), 325 -369.

Strotz, R.H., 1955. Myopia and inconsistency in dynamic utility maximization. The Review of Economic Studies 23 (3), 165-180.

Tabellini, G., 2008. Institutions and culture. Journal of the European Economic Association 6 (2-3), 255-294.

Tan, C.T., Johnson, R.D., 1996. To wait or not to wait: The influence of culture on discounting behavior. In: Loke, W.H. (Ed.), Perspectives on judgment and decision making. Scarecrow, Lanham, MD.

Tanaka, T., Camerer, C.F., Nguyen, Q., 2010. Risk and time preferences: Linking experimental and household survey data from vietnam. American Economic Review 100 (1), 557-571.

Triandis, H.C., 1971. Some psychological dimensions of modernization. Proceedings of the 17th International Congress of Applied Psychology (Vol. II).

Trostel, P.A., Taylor, G.A., 2001. A theory of time preference. Economic inquiry 39 (3), 379-395.

Wang, M., Rieger, M.O., Hens, T., 2016. How time preferences differ: Evidence from 53 countries. Journal of Economic Psychology 52, 115-135.

Warner, J.T., Pleeter, S., 2001. The personal discount rate: Evidence from military downsizing programs. American Economic Review 91 (1), 33-53.

Weber, M., 1930. The Protestant Ethic and the "Spirit” of Capitalism. Scribner's, New York. 